\title{
The sensitivity of aerosol in Europe to two different emission inventories and temporal distribution of emissions
}

\author{
A. de Meij ${ }^{1}$, M. Krol ${ }^{1, *}$, F. Dentener ${ }^{1}$, E. Vignati ${ }^{1}$, C. Cuvelier ${ }^{1}$, and P. Thunis ${ }^{1}$ \\ ${ }^{1}$ Institute for Environment and Sustainability, Joint Research Centre, European Commission, Ispra, Italy \\ *now at: SRON, Utrecht, the Netherlands, and Wageningen University, The Netherlands
}

Received: 7 December 2005 - Published in Atmos. Chem. Phys. Discuss.: 18 April 2006

Revised: 11 July 2006 - Accepted: 18 September 2006 - Published: 25 September 2006

\begin{abstract}
The sensitivity to two different emission inventories, injection altitude and temporal variations of anthropogenic emissions in aerosol modelling is studied, using the two way nested global transport chemistry model TM5 focussing on Europe in June and December 2000. The simulations of gas and aerosol concentrations and aerosol optical depth (AOD) with the EMEP and AEROCOM emission inventories are compared with EMEP gas and aerosol surface based measurements, AERONET sun photometers retrievals and MODIS satellite data.
\end{abstract}

For the aerosol precursor gases $\mathrm{SO}_{2}$ and $\mathrm{NO}_{\mathrm{x}}$ in both months the model results calculated with the EMEP inventory agree better (overestimated by a factor 1.3 for both $\mathrm{SO}_{2}$ and $\mathrm{NO}_{\mathrm{x}}$ ) with the EMEP measurements than the simulation with the AEROCOM inventory (overestimated by a factor 2.4 and 1.9 , respectively).

Besides the differences in total emissions between the two inventories, an important role is also played by the vertical distribution of $\mathrm{SO}_{2}$ and $\mathrm{NO}_{\mathrm{x}}$ emissions in understanding the differences between the EMEP and AEROCOM inventories.

In December $\mathrm{NO}_{\mathrm{x}}$ and $\mathrm{SO}_{2}$ from both simulations agree within $50 \%$ with observations.

In June $\mathrm{SO}_{4}^{=}$evaluated with the EMEP emission inventory agrees slightly better with surface observations than the AEROCOM simulation, whereas in December the use of both inventories results in an underestimate of $\mathrm{SO} 4$ with a factor 2. Nitrate aerosol measured in summer is not reliable, however in December nitrate aerosol calculations with the EMEP and AEROCOM emissions agree with $30 \%$, and $60 \%$, respectively with the filter measurements. Differences are caused by the total emissions and the temporal distribution of the aerosol precursor gases $\mathrm{NO}_{\mathrm{x}}$ and $\mathrm{NH}_{3}$. Despite these differences, we show that the column integrated AOD is less sensitive to the underlying emission inventories. Calculated AOD

Correspondence to: A. de Meij

(alexander.de-meij@jrc.it) values with both emission inventories underestimate the observed AERONET AOD values by $20-30 \%$, whereas a case study using MODIS data shows a high spatial agreement.

Our evaluation of the role of temporal distribution of anthropogenic emissions on aerosol calculations shows that the daily and weekly temporal distributions of the emissions are only important for $\mathrm{NO}_{\mathrm{x}}, \mathrm{NH}_{3}$ and aerosol nitrate. However, for all aerosol species $\mathrm{SO}_{4}^{=}, \mathrm{NH}_{4}^{+}$, $\mathrm{POM}, \mathrm{BC}$, as well as for $\mathrm{AOD}$, the seasonal temporal variations used in the emission inventory are important. Our study shows the value of including at least seasonal information on anthropogenic emissions, although from a comparison with a range of measurements it is often difficult to firmly identify the superiority of specific emission inventories, since other modelling uncertainties, e.g. related to transport, aerosol removal, water uptake, and model resolution, play a dominant role.

\section{Introduction}

Greenhouse gases and aerosols play an important role in climate change (Charlson et al., 1991; Kiehl and Briegleb, 1993). Greenhouse gases reduce the emission of long wave radiation back to space, leading to a warming of the atmosphere. Aerosol can change the atmosphere's radiation budget by reflecting or absorbing incoming radiation (direct effect) and by modifying cloud properties (indirect effect). Quantification of the role of aerosols on the Earth's radiation balance is more complex than for greenhouse gases, because aerosol mass and particle number concentrations are highly variable in space and time, and the optical properties of aerosol are uncertain.

A good estimate of the emissions of aerosol precursor gases and primary aerosols in the emission inventories is therefore crucial for estimating aerosol impacts on air quality and climate change, and evaluating coherent reduction strategies.

Published by Copernicus GmbH on behalf of the European Geosciences Union. 
Two major uncertainties of the current regional and global scale emission inventories comprise the accurate estimation of the quantity of the aerosols and precursor emissions, and the role of the temporal distribution of the emissions in the inventories.

Whereas some work on the impact of the temporal distribution of emissions on photochemistry in regional and urban areas has been performed (e.g. Pont and Fontan, 2001; Pryor and Steyn, 1995; Jenkin et al., 2002), to our knowledge no studies have been devoted to evaluate its impact on aerosol surface concentrations and mid-visible aerosol optical depths (AODs). The latter is an important parameter that is needed to calculate the Angstrom parameter, which provides information on the size of the particles in a given atmospheric column.

This study has two main objectives. The first objective is to evaluate uncertainties in gas, aerosol and aerosol optical depth calculations, resulting from two widely used emission inventories focussing on Europe. To this end we performed with the global transport chemistry TM5 model simulations using a zoom over Europe, for which we had two different emission inventories available, EMEP and AEROCOM. The European scale EMEP inventory has been used for many years in the evaluation of emission reduction strategies, and contains reported emissions by member countries, as well as expert estimates. The AEROCOM project provided a compilation of recommended global scale aerosol and precursor emission inventories for the year 2000 and was used in the recent AEROCOM global aerosol module intercomparison (Kinne et al., 2006; Textor et al., 2006; Dentener et al., 2006).

The second objective is to evaluate the role of the temporal and height distribution of the emissions on aerosol (precursor) concentrations and AOD calculations. For this we performed simulations using the EMEP inventory, with the standard recommendations on the temporal distribution of emissions (including seasonal variability) and compared it to a simulation ignoring daily emissions variations and another simulation that used annual averaged emissions.

The model performance was evaluated comparing aerosol precursor gases $\left(\mathrm{NO}_{\mathrm{x}}, \mathrm{SO}_{2}, \mathrm{NH}_{3}\right)$ and aerosols components $\left(\mathrm{SO}_{4}^{=}, \mathrm{NH}_{4}^{+}, \mathrm{NO}_{3}^{-}\right.$, black carbon (BC) and particulate organic matter (POM)) to the EMEP network surface observations and to AERONET and MODIS AOD focussing on June and December 2000, over Europe.

Section 2 deals with the description of the simulations, model and emission inventories. In Sect. 3 a description of the remote sensing data and measurement data is given. In Sect. 4 the results are presented. We discuss the results in Sect. 5 and we finish with conclusions in Sect. 6.

\section{Methodology}

Using the two way nested global chemistry transport model TM5, we performed four simulations for the year 2000. Out- put was analyzed for a summer (June) and winter (December) month to highlight the seasonal dependency of emissions and their interaction with the different meteorological conditions prevailing in summer and winter.

The first simulation (further denoted as $\mathrm{S}_{\mathrm{EMEP}}$ ) uses the EMEP inventory for the European domain, including their temporal (including, daily, weekly and seasonal variability) and height distribution. The second simulation $\mathrm{S}_{\mathrm{AERO}}$ used the AEROCOM recommended emission inventory. The third simulation, $\mathrm{S}_{\mathrm{EMEP} \_c}$, ignored the weekly and daily temporal distribution of emissions, but seasonal temporal distributions are still included. Finally we performed a simulation for which a seasonally constant temporal distribution was implemented, SEMEP_c_annual.

\subsection{The nested TM5 model}

The TM5 model is an off-line global transport chemistry model (Bergamaschi et al., 2005; Krol et al., 2005; Peters et al., 2004) driven by meteorological ECMWF (European Centre for Medium-Range Weather Forecasts) data. The presently used configuration of TM5 has a spatial global resolution of $6^{\circ} \times 4^{\circ}$ and a two-way zooming algorithm that allows resolving regions, e.g. Europe, Asia, N. America and Africa, with a finer resolution of $1^{\circ} \times 1^{\circ}$. A domain of $3^{\circ} \times 2^{\circ}$ has been added, to smooth the transition between the global and finer region. The zooming algorithm gives the advantage of a high resolution at measurement locations. The vertical structure has 25 hybrid sigma-pressure layers. In this study the $1^{\circ} \times 1^{\circ}$ resolution was used for Europe/North African region spanning from $21^{\circ} \mathrm{W}$ to $39^{\circ} \mathrm{E}$ and from $12^{\circ} \mathrm{S}$ to $66^{\circ} \mathrm{N}$.

Transport, chemistry, deposition and emissions are solved using the operator splitting. The slopes advection scheme (Russel and Lerner, 1981) has been implemented and deep and shallow cumulus convection is parameterised according to Tiedtke (1989).

The gas phase chemistry is calculated using the CBM-IV chemical mechanism (Gery et al., 1989a, b) solved by means of the EBI (Eulerian Backward Iterative) method (Hertel et al., 1993), like in the parent TM3 model, which has been widely used in many global atmospheric chemistry studies (Houweling et al., 1998; Peters et al., 2002; Dentener et al., 2003). In the current model version $\mathrm{CO}, \mathrm{NMVOC}, \mathrm{NH}_{3}$, $\mathrm{SO}_{2}$ and $\mathrm{NO}_{\mathrm{x}}$ gas phase, and $\mathrm{BC}$ (black or elemental carbon), $\mathrm{POM}$ (particulate organic matter), mineral dust, sea salt (externally mixed), $\mathrm{SO}_{4}^{=}, \mathrm{NO}_{3}^{-}, \mathrm{NH}_{4}^{+}$aerosol components were included. Mineral dust and sea salt (SS) were described using a log-normal distribution (3 for SS, 2 for dust) and their aerosol number and mass were separately transported using a fixed standard deviation of the size distribution (Vignati et al., 2005). The aerosol components $\mathrm{SO}_{4}^{=}$, methane sulfonic acid (MSA) $\mathrm{NO}_{3}^{-}, \mathrm{NH}_{4}^{+}, \mathrm{POM}$, and $\mathrm{BC}$, were included assuming that they were entirely present in the accumulation mode and externally mixed. In this first aerosol version of TM5, aerosol dynamics (coagulation, nucleation, 
condensation and evaporation) are not included. However, gas-aerosol equilibrium of inorganic salts and water uptake is considered using the Equilibrium Simplified Aerosol Model (EQSAM version v03d, Metzger, 2000; Metzger et al., 2002a, b). This model allows non-iterative calculation of the equilibrium partitioning of major aerosol compounds of the ammonia $\left(\mathrm{NH}_{4}\right)$, nitric acid $\left(\mathrm{NO}_{3}\right)$, sulphuric acid $\left(\mathrm{SO}_{4}\right)$ and water system. EQSAM assumes internally mixed aerosols and that the water activity of an aqueous aerosol is equal to the ambient $R H$ (relative humidity). Hence, aerosol water is a diagnostic rather than transported model parameter. Water uptake on SS, is calculated using the description of Gerber et al. (1985).

Formation of secondary organic aerosol was not explicitly described, but included as pseudo organic aerosol emissions for the AEROCOM simulation but not for the simulation using EMEP emissions (see Sect. 2.3.2).

Dry deposition is parameterized according to Ganzeveld (1998). In-cloud as well as below-cloud wet removal are parameterized differently for convective and stratiform precipitation, building on the work of Guelle et al. (1998), and Jeuken et al. (2001).

For BC and POM we assume $100 \%$ hydrophilic properties in our model, and hence we assume that BC/POM is removed by wet and dry depositional processes like soluble inorganic aerosol $\left(\mathrm{SO}_{4}^{=}\right)$. TM5 utilized information from the 6-h IPS forecast on 3-D cloud cover and cloud liquid water content, convective and stratiform rainfall rates at the surface, and surface heat fluxes to calculated convection.

Removal by convective clouds is taken into account by removing aerosols and gases in convective updrafts- with a correction for sub-grid effects on the larger model scale.

Removal by stratiform clouds considers precipitation formation and evaporation, and cloud cover, and takes into account a grid-dependency. Effectively rain-out on smaller grids works more effectively than on larger grids. Removal of gases further take their Henry solubility into account. For aerosol we used an in-cloud wet removal efficiency of $70 \%$ for the soluble aerosols and a below cloud removal efficiency of $100 \%$. Sedimentation was only taken into account for dust and sea salt (large particles) and is considered to be negligible for the sub-micron accumulation mode.

\subsection{Aerosol size distribution and AOD calculation}

For optical calculations, the accumulation mode aerosol, comprising sulphate, nitrate, ammonium, aerosol water, POM and BC, is described by a fixed Whitby lognormal distribution, using a dry particle median radius of $0.034 \mu \mathrm{m}$ and standard deviation $(\sigma)$ 2.0. As mentioned before, dust and sea salt are described with multi-model lognormal distribution. Aerosol mass and number are transported separately, and as a consequence, the size distribution is allowed to change due to transport and deposition. Two modes are considered for anthropogenic dust (accumulation, $\sigma=1.59$ and coarse, $\sigma=2.0$ ) and three modes for sea salt (Aitken, $\sigma=1.59$, accumulation, $\sigma=1.59$ and coarse, $\sigma=2.0$ ). As described before, water uptake by the aerosol is taken into account and modify the above mentioned diameters.

To calculate aerosol optical depth (AOD) at $550 \mathrm{~nm}$, we use the Mie code provided by O. Boucher (2004, personal communication) to pre-calculate a look-up table for a number of refractive indices and lognormal distributions. The optical properties of these lognormal distributions are determined by numerical interpolation in discrete size intervals corresponding to the median diameter. In Table $S 1$ of the electronic supplement (ES, http://www.atmos-chem-phys.net/6/ 4287/2006/acp-6-4287-2006-supplement.pdf) the densities and optical properties that are used for the optical calculations are listed.

\subsection{Emission data}

In this study we used two independent emission inventories for aerosol and aerosol precursor gases for the year 2000. (i) The $50 \mathrm{~km} \times 50 \mathrm{~km}$ European scale EMEP inventory, which is widely used for air quality studies in Europe, and (ii) the $1^{\circ} \times 1^{\circ}$ global AEROCOM inventory, which is used for climate modelling studies. Below, a brief description of the two emission inventories is given, together with the major differences between the two inventories. In ES Table S2 (http://www.atmos-chem-phys.net/ 6/4287/2006/acp-6-4287-2006-supplement.pdf), we present an overview of the species which are included in the two emission inventories.

\subsubsection{EMEP emission inventory}

The Co-operative Programme for Monitoring and Evaluation of the Long-range Transmission of Air Pollutants in Europe (EMEP) evaluates air quality in Europe by operating a measurement network, as well as performing model assessments.

The EMEP emission inventory (http://aqm.jrc.it/eurodelta and http://webdab.emep.int/) contains reported anthropogenic emission data for each European country, complemented by expert judgements when incomplete or erroneous data reports are detected. The $50 \mathrm{~km} \times 50 \mathrm{~km}$ emission inventory contains $\mathrm{SO}_{2}, \mathrm{NO}_{\mathrm{x}}$ (as $\mathrm{NO}_{2}$ ), $\mathrm{NH}_{3}, \mathrm{NMVOC}, \mathrm{CO}$, PM2.5 and PMcoarse for 11 CORINAIR source sectors. The emissions are temporally distributed per source sector using time factors. We consider hourly (a multiplication factor that changes each hour and modifies the daily emission), daily (a factor that changes the weekly emissions) and seasonally (a factor that changes each month, thus altering the seasonal distribution). For instance, it is important for traffic to include rush-hours and weekday-weekend driving patterns, and also the intensity of domestic heating differs from winter to summer. To match the PM2.5 emissions with the components used in TM5 we assumed the following mass fractions: POM 35\%, anthropogenic dust 15\%, BC $25 \%$ and 
sulphate 25\%, based on Putaud et al. (2003). PM coarse is assumed to contain dust only. We added from the global AEROCOM emission inventory biomass burning, natural dust, sea salt and volcanic emissions for the year 2000 (see Sect. 2.3.2). Outside Europe we also use the AEROCOM inventory. ES Table S3 (http://www.atmos-chem-phys.net/ 6/4287/2006/acp-6-4287-2006-supplement.pdf) provides an overview of the 11 CORINAIR source sectors, together with the emissions per sector. Gas and PM emissions are distributed to different height levels based on the sector they belong to. Point sources and volcanoes are added to the appropriate height, see ES Table S4. Note that unlike for the AEROCOM inventory, we did not consider pseudo-SOA emissions.

\subsubsection{AEROCOM emission inventory}

AEROCOM (an AEROsol module inter-COMparison in global models, see http://nansen.ipsl.jussieu.fr/AEROCOM) evaluates aerosol concentrations, optical properties, and removal processes in 21 global models (Kinne et al., 2006; Textor et al., 2006). AEROCOM experiment B aims at constraining the models by providing a prescribed set of global natural and anthropogenic emissions for the year 2000. We briefly call this ad-hoc compilation of the best inventories that was available in the year 2003 the AEROCOM inventory, ftp://ftp.ei.jrc.it/pub/Aerocom (Dentener et al., 2006).

Monthly varying large scale biomass burning emissions of POM, BC and $\mathrm{SO}_{2}$ are based on GFED 2000 (Global Fire Emissions Database) (Van der Werf et al., 2003). Global emissions amount to $34.7 \mathrm{Tg}, 3.06 \mathrm{Tg}$ and $4.11 \mathrm{Tg}\left(\mathrm{SO}_{2}\right)$, respectively. Fossil fuel/bio fuel related POM (12.3 Tg $\mathrm{POM} / \mathrm{yr}$ ) and $\mathrm{BC}$ (4.6 Tg C/year) emissions are based on Bond et al. (2004). Country and region based $\mathrm{SO}_{2}$ emissions for the year 2000 are provided by IIASA (Dentener et al., 2006; Cofala et al., 2005) and geographically distributed with the EDGAR3.2 1995 data base. Global emissions amount to $138.3 \mathrm{Tg} \mathrm{SO} 2 /$ year and $3.5 \mathrm{Tg} \mathrm{\textrm {SO } _ { 4 }}$ /year. Natural emissions of $\mathrm{SO}_{2}$ (e.g. volcanoes) are an update of the GEIA recommended datasets.

Daily averaged DMS emissions were taken from the LMDZ model (O. Boucher, 2003, personal communication) using the DMS surface water concentrations of Kettle and Andreae (2000) and the horizontal wind speed (Nightingale et al., 2000). Yearly DMS amount to $20.8 \mathrm{TgS}$. Daily sea salt emissions were taken from Gong (2002, 2003a, b), interpolated to a three modal distribution with a cut-off at $\mathrm{r}=10 \mu \mathrm{m}$, resulting in $8356 \mathrm{Tg} /$ year. Similarly, daily dust emissions for 2000 are based on Ginoux (2004), were interpolated to 2 lognormal modes, corresponding to a global total of $1681 \mathrm{Tg} / \mathrm{yr}$.

Secondary organic aerosol is an important component of the aerosol system (Kanakidou et al., 2005). Since most AEROCOM models did not include a description of the formation of SOA (Secondary Organic Aerosol), and there are major difficulties to describe the formation pro- cesses of SOA, AEROCOM therefore made the simplifying assumption that $15 \%$ of natural terpene emissions form SOA, altogether amounting to $19.11 \mathrm{Tg} \mathrm{POM} /$ year. In the TM5 model most other anthropogenic emissions such as $\mathrm{NO}_{\mathrm{x}}$ are taken from the EDGAR3.2 (1995) database, http://www.mnp.nl/edgar. $\mathrm{NH}_{3}$ emissions were based on Bouwman et al. (1997, 2002), and distributed using the hours of daylight per month after Dentener and Crutzen (1994). For the other components the yearly emissions are equally distributed over the year with no seasonal variations. ES Table S5 (http://www.atmos-chem-phys.net/6/ 4287/2006/acp-6-4287-2006-supplement.pdf) includes the height of the emissions which are applied in the AEROCOM emission inventory.

\subsubsection{EMEP emission inventory versus AEROCOM emis- sion inventory}

There are substantial differences between the two emission inventories in describing BC, dust, POM, and sulphate emissions. The EMEP inventory contains detailed country based knowledge on a $50 \times 50 \mathrm{~km}$ resolution, while the AEROCOM inventory offers the advantage of global consistency. EMEP reports PM2.5 emissions, which were disaggregated by us into individual aerosol components. For example, we assume that $25 \%$ and $35 \%$ of the PM2.5 emissions consists of $\mathrm{BC}$ and POM, while the AEROCOM BC and POM emissions are based on a technology based global inventory of black carbon emissions from fossil fuel and bio-fuel combustion (Bond et al., 2004). 15\% of the EMEP PM2.5 is assumed to be anthropogenic dust (e.g. vehicular movements causing re-suspension of particles), while AEROCOM contains only natural dust emissions (Ginoux et al., 2004). Particularly relevant for this study are the emissions from the Sahara. Finally, we assume that the remaining $25 \%$ of the EMEP PM2.5 emissions is primary sulphate. In the AEROCOM simulation we assume that $2.5 \%$ of all $\mathrm{SO}_{\mathrm{x}}$ of the AEROCOM emissions is emitted as primary sulphate. These different procedures result for the European domain in different primary sulphate emissions of 0.22 and $0.23 \mathrm{Tg} /$ year, respectively.

Focussing on the European domain, we give in ES Table S6 (http://www.atmos-chem-phys.net/6/4287/2006/ acp-6-4287-2006-supplement.pdf) an overview of the resulting total emissions of $\mathrm{NO}_{\mathrm{x}}, \mathrm{CO}, \mathrm{SO}_{2}, \mathrm{NH}_{3}, \mathrm{SO}_{4}$, sea salt, $\mathrm{BC}, \mathrm{POM}$ and dust included in the two inventories for $\mathrm{Eu}-$ rope in June, December and the annual amount.

The annual emissions of the two inventories are generally within 20\%, however the annual AEROCOM POM emissions are higher by $45 \%, \mathrm{NH} 3$ by $37 \%$ and mineral dust by $34 \%$. The difference between the European scale $\mathrm{NH}_{3}$ AEROCOM (6.0 Tg) and EMEP (4.4 Tg) emissions stems likely from the recent $\mathrm{NH}_{3}$ emission abatement measures to combat eutrophication problems in Northern Europe. These are included in the EMEP, but not in the Bouwman et al. (2002) in- 
ventory. The much larger POM emissions in the AEROCOM inventory are due to the presence of SOA pseudo-emissions, which were not included in the EMEP emission inventory.

The differences in dust emissions are only due to the anthropogenic dust sources from agriculture and transport included in the EMEP inventory. These emissions are added to the natural mineral dust from AEROCOM which was included in both inventories.

Larger differences appear in June, where we see that AEROCOM emissions of $\mathrm{NO}_{\mathrm{x}}, \mathrm{SO}_{2}, \mathrm{SO}_{4}, \mathrm{NH}_{3}$, and $\mathrm{POM}$ are higher by $39 \%, 18 \%, 31 \%, 67 \%$ and $248 \%$, respectively. Except for POM, these differences are mainly due to the seasonal time factors which are applied to the EMEP inventory only.

For December (ES Table S6, http: //www.atmos-chem-phys.net/6/4287/2006/ acp-6-4287-2006-supplement.pdf) the above mentioned discrepancies are smaller than in June, due to compensating effect of the seasonal distribution and the yearly discrepancies of the two inventories.

\section{Description measurement data sets}

For evaluation of the computed gas and aerosol concentrations we compare with EMEP measurements of $\mathrm{SO}_{2}, \mathrm{NO}_{\mathrm{x}}$, and aerosol components. Model calculated AOD is compared with sun photometer data from the AERONET stations located in Europe, and MODIS (Moderate Resolution Imaging Spectro radiometer) satellite data.

The EMEP air quality monitoring network measures since the late 1970s ozone, heavy metals, Persistent Organic Pollutants (POPs), Volatile Organic Compounds (VOC) and particulate matter (PM2.5, PM10, $\mathrm{SO}_{4}^{=}, \mathrm{NO}_{3}^{-}$and $\mathrm{NH}_{4}^{+)}$at ca. 150 sites in Europe. The aerosols are measured with a daily time resolution; $\mathrm{SO}_{2}$ and $\mathrm{NO}_{\mathrm{x}}$ are reported hourly. Not every station measures all components, therefore the number of EMEP stations available for comparison with model results differs per component.

One of the artefacts occurring with the main filter type (quartz) used by most EMEP stations is the evaporation of ammonium nitrate at higher temperatures. Temperatures exceeding $20^{\circ} \mathrm{C}$ cause complete $\mathrm{NH}_{4} \mathrm{NO}_{3}$ evaporation from the quartz filter, a loss of $100 \%$; and a loss of about $25 \%$ for $\mathrm{NH}_{4}^{+}$, based on $5-10 \mu \mathrm{g} / \mathrm{m}^{3} \mathrm{NO}_{3}^{-}$and 10 $20 \mu \mathrm{g} / \mathrm{m}^{3} \mathrm{SO}_{4}^{=}$at Ispra during a summer month (ratio $2: 1$ for $\left.\left(\mathrm{NH}_{4}\right)_{2} \mathrm{SO}_{4} / \mathrm{NH}_{4} \mathrm{NO}_{3}\right)$.

Temperatures between 20 and $25^{\circ} \mathrm{C}$ cloud lead to a loss of $50 \%$ of the nitrate aerosol (Schaap et al., 2003a, b). Therefore almost all reported summer $\mathrm{NH}_{4} \mathrm{NO}_{3}$ and $\mathrm{NH}_{4}^{+}$concentrations present only a lower limit, rather than a realistic concentration.

The AERONET (AErosol RObotic NETwork) Cimel sun photometers (Holben et al., 1998) used in this study are given in ES Table S7 (http://www.atmos-chem-phys.net/6/4287/ 2006/acp-6-4287-2006-supplement.pdf). Due to cloudiness not all days of June and December could be used for aerosol retrieval. The sun photometer measures (every $15 \mathrm{~min}$ ) in a $1.2^{\circ}$ field of view, at eight solar spectral bands (340, 380, $440,500,670,870,940$ and $1020 \mathrm{~nm}$ ). These solar extinction measurements are used to calculate for each wavelength the aerosol optical depth, with an accuracy of $\pm 0.01-0.02$ (Eck et al., 1999). Sun photometer acquires aerosol data only during daylight and in cloud free conditions. In this work the cloud screened and quality-assured level 2 data are used.

We used AOD at $550 \mathrm{~nm}$, calculated from the AOD values reported at 870 and $440 \mathrm{~nm}$, using the information on the Angström coefficient (S. Kinne, personal communication, 2004).

The MODIS (Moderate Resolution Imaging Spectro radiometer) on board of NASA's Terra Earth Observing System (EOS) mission retrieves aerosol over land (Kaufman et al., 1997) and ocean (Tanré et al., 1997) at high resolution. MODIS has one NADIR looking camera which retrieves data in 36 spectral bands, from $0.4 \mu \mathrm{m}-14.5 \mu \mathrm{m}$ with spatial resolutions of $250 \mathrm{~m}$ (bands 1-2), $500 \mathrm{~m}$ (bands 3-7) and $1000 \mathrm{~m}$ (bands 8-36). Daily level 2 (MOD04) aerosol optical thickness data are produced at the spatial resolution of $10 \times 10 \mathrm{~km}$ over land, aggregated from the original $1 \mathrm{~km} \times 1 \mathrm{~km}$ pixel size. As the swath width is about $2330 \mathrm{~km}$, the instrument has almost a daily global coverage. Uncertainties in the MODIS products over land are relatively large. High albedo areas like the Sahara Desert and snow/ice covered regions and complex terrain are difficult for the MODIS instrument, leading to a large bias with models and ground based observations (Chin et al., 2004). Reported MODIS aerosol errors are $\Delta \tau_{a}= \pm 0.05 \pm 0.15 \tau_{a}$ (Remer et al., 2005). Level 2 cloud screened, version 003 files are used for this work. We present in Sect. 4 a case study for the 11 June 2000.

\section{Results}

In this section we present first an evaluation of the impact of using the EMEP and AEROCOM inventories ( $\mathrm{S}_{\mathrm{EMEP}}$ and $\mathrm{S}_{\mathrm{AERO}}$ ) and compare them with EMEP measurements (Sect. 4.1). In Sect. 4.2 we subsequently demonstrate the spatial variability of AOD associated with using these two emissions inventories, and compare it to MODIS retrievals. In Sect. 4.3 we assess the temporal variability of AOD by comparing to AERONET sun photometer data. Finally in Sect. 4.4, we perform two sensitivity studies to analyse the impact of daily, weekly and seasonal temporal distribution of emissions on gas, aerosol and AOD calculations. For the interested reader, detailed station information and statistics per component are presented in the accompanied electronic supplement to this paper. 

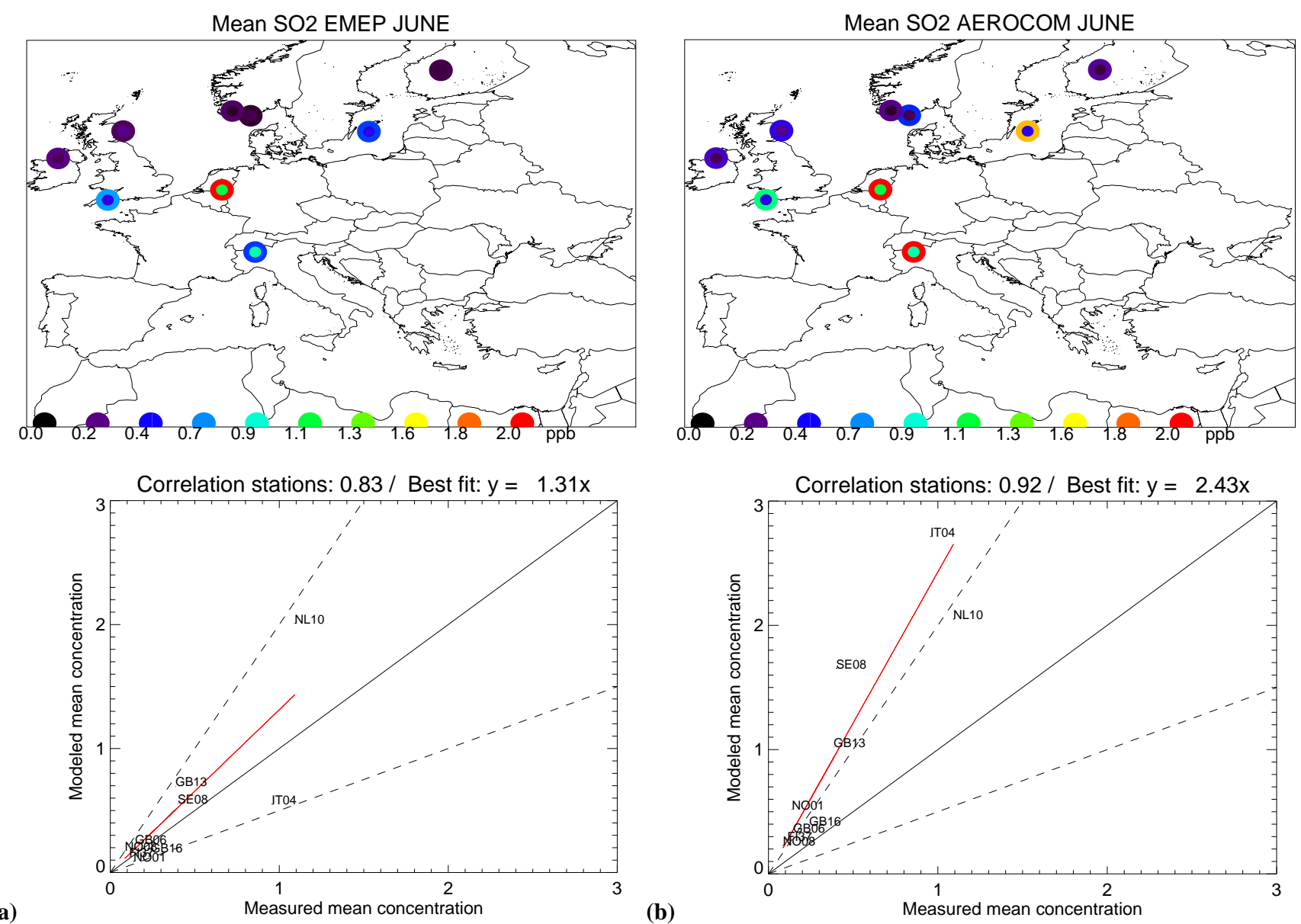

(a)

Fig. 1. (a), (b), (c) and (d) are presenting the monthly average measured mixing ratio (inner circle) of $\mathrm{SO}_{2}$ and calculated (outer circle) $\mathrm{SO}_{2}$

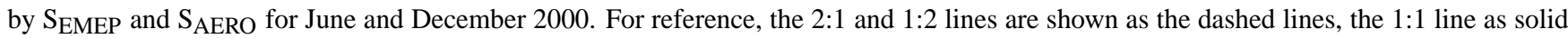
and the line of best fit is red solid. termined the spatial correlation using the monthly averaged concentration, and calculate the model bias.

We evaluate the sulphate and nitrate aerosol precursor gases $\mathrm{SO}_{2}$, and $\mathrm{NO}_{\mathrm{x}}$, and the aerosol components $\mathrm{SO}_{4}^{=}$, $\mathrm{NO}_{3}^{-}, \mathrm{NH}_{4}^{+}$and $\mathrm{BC}$. The overall evaluation is presented in Figs. 1, 2 and 3, which shows the monthly mean concentration distribution over Europe.

\subsection{1 $\quad \mathrm{SO}_{2}$}

In Figs. 1a-d we present an evaluation of $\mathrm{S}_{\mathrm{EMEP}}$ and $\mathrm{S}_{\mathrm{AERO}}$ computed $\mathrm{SO}_{2}$ concentrations. In June, both simulations show high spatial correlation coefficients, of 0.83 and 0.92 , respectively (based on 9 stations, 68 station rejected). The June mean $\mathrm{SO}_{2}$ concentrations for $\mathrm{S}_{\mathrm{EMEP}}$ are in better agreement (an overestimate of $31 \%$ ) with the measured values than $\mathrm{S}_{\mathrm{AERO}}$ (an overestimate by a factor 2.4 ). This discrepancy can not be explained by differences in the emissions alone, since the AEROCOM emissions of $\mathrm{SO}_{2}$ are only $18 \%$ higher over Europe than the EMEP inven- 

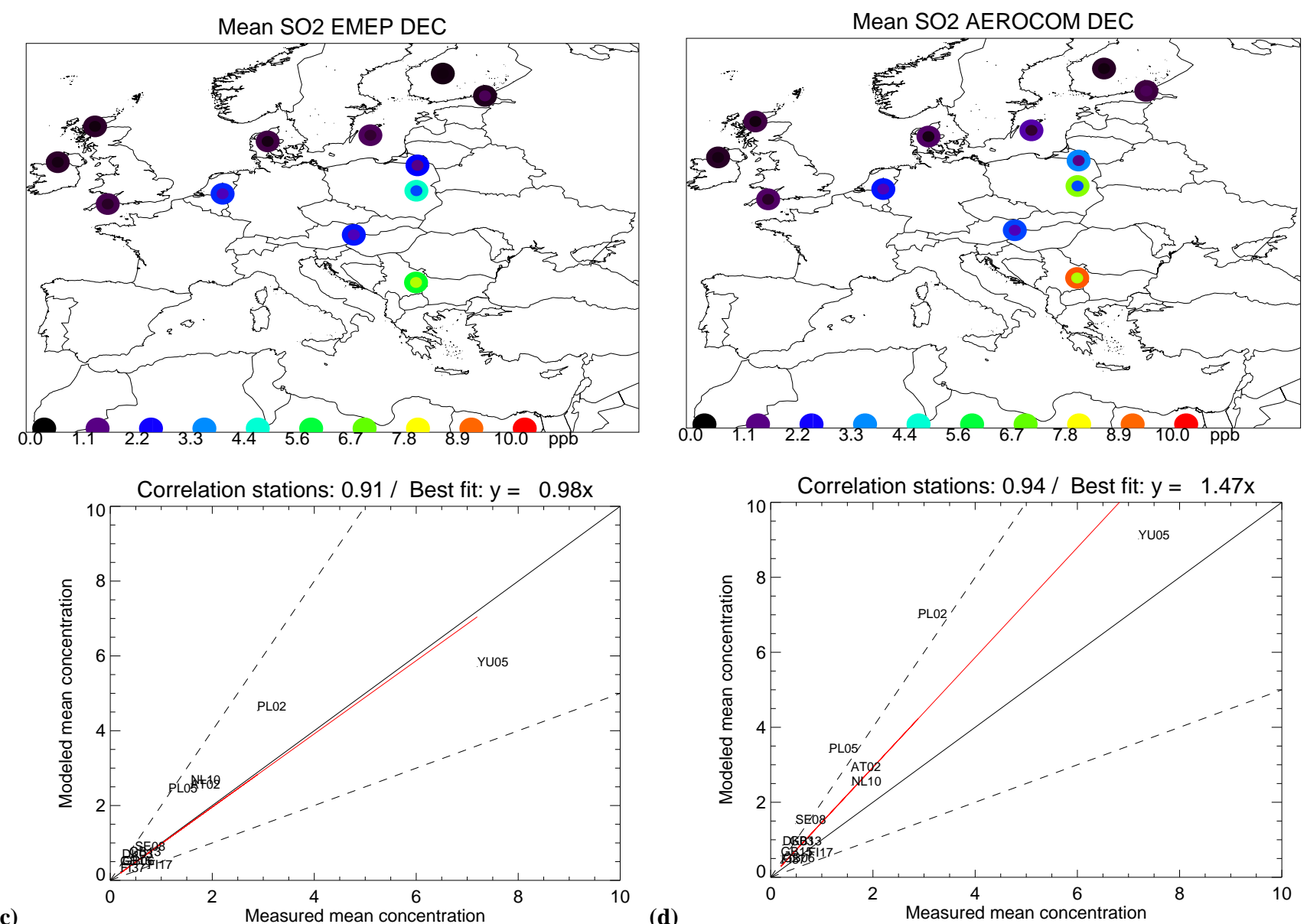

Fig. 1. Continued.

tory (ES Table S6, http://www.atmos-chem-phys.net/6/4287/ 2006/acp-6-4287-2006-supplement.pdf). A likely explanation lies in the vertical distribution of the emissions applied in the inventories (ES Tables S4 and S5). For that reason we present in Figs. $2 \mathrm{a}$ and $\mathrm{b}$ the June mean $\mathrm{SO}_{2}$ surface concentrations. Especially in the eastern part of Europe the $\mathrm{SO}_{2}$ concentrations by $\mathrm{S}_{\mathrm{AERO}}$ at ground level are up to a factor of 2 higher due to the higher fraction of emissions in the lowest model layer. When we compare the $\mathrm{SO}_{2}$ distributions at $950 \mathrm{hPa}( \pm 500 \mathrm{~m}$, Figa. $2 \mathrm{c}$ and d) we observe especially in Eastern Europe an opposite situation; smaller $\mathrm{SO}_{2}$ emissions from domestic heating (contributing by $6.8 \%$ to all emissions). In $\mathrm{S}_{\mathrm{AERO}} \mathrm{SO}_{2}$ is emitted at ground level only, which could be held responsible for the higher $\mathrm{SO} 2$ concentrations at ground level, where in EMEP 50\% of $\mathrm{SO}_{2}$ is emitted at a higher level.

For December the difference between the $\mathrm{SO}_{2}$ calculations by $\mathrm{S}_{\mathrm{EMEP}}$ and $\mathrm{S}_{\mathrm{AERO}}$ is much smaller, see Figs. $1 \mathrm{c}$ and $\mathrm{d}$ (based on 12 stations used and 66 rejected). On a monthly averaged basis $\mathrm{S}_{\mathrm{EMEP}}$ concentrations are $2 \%$ lower than the measurements, with a spatial correlation coefficient of 0.91 .
$\mathrm{S}_{\mathrm{AERO}}$ overestimates the measurements with $47 \%$ and has a high spatial correlation of 0.94 . Note that the high correlation coefficients are statistically not robust (Figs. 1c and d), since they are determined by a few stations with a high spread in the monthly mean concentrations. The better agreement for the two simulations in December is in line with the smaller differences $(2 \%)$ between the two emission inventories (see ES Table S6, http://www.atmos-chem-phys.net/ 6/4287/2006/acp-6-4287-2006-supplement.pdf). Tables S9a and $\mathrm{S} 9 \mathrm{~b}$ of the electronic supplement contain for each station the calculated monthly mean and correlation coefficients for $\mathrm{S}_{\mathrm{EMEP}}$ and $\mathrm{S}_{\mathrm{AERO}}$ together with the measured monthly mean and the number of measurements for June and December.

\subsection{2 $\mathrm{NO}_{\mathrm{x}}$}

In June, $\mathrm{S}_{\mathrm{EMEP}}$ slightly overestimates (by $28 \%$ ) the monthly mean $\mathrm{NO}_{\mathrm{x}}$ values, while the $\mathrm{S}_{\mathrm{AERO}}$ simulation overestimates $\mathrm{NO}_{\mathrm{x}}$ by a factor of 1.95 (not shown). Spatial correlation coefficients are 0.79 and 0.53 , respectively (based on 11 stations, 49 rejected). The difference 

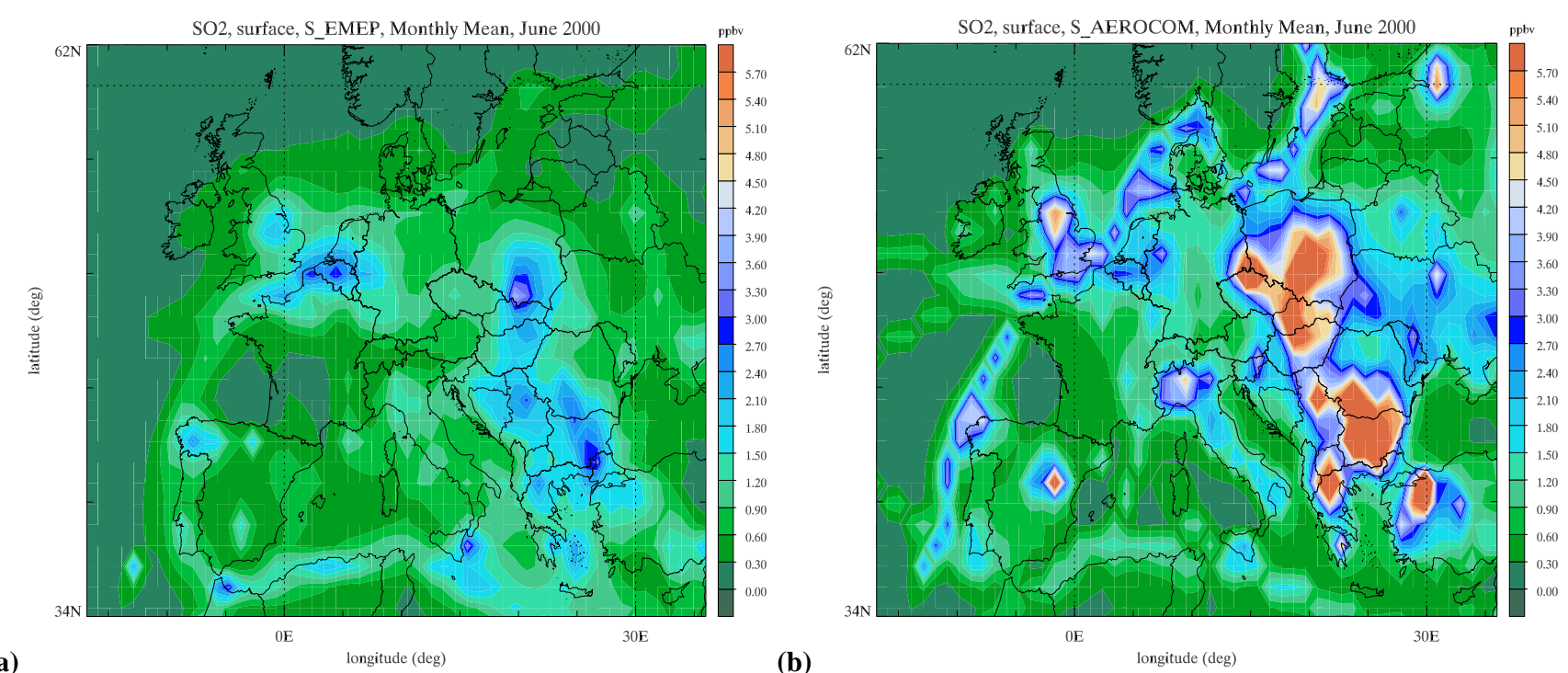

(a)

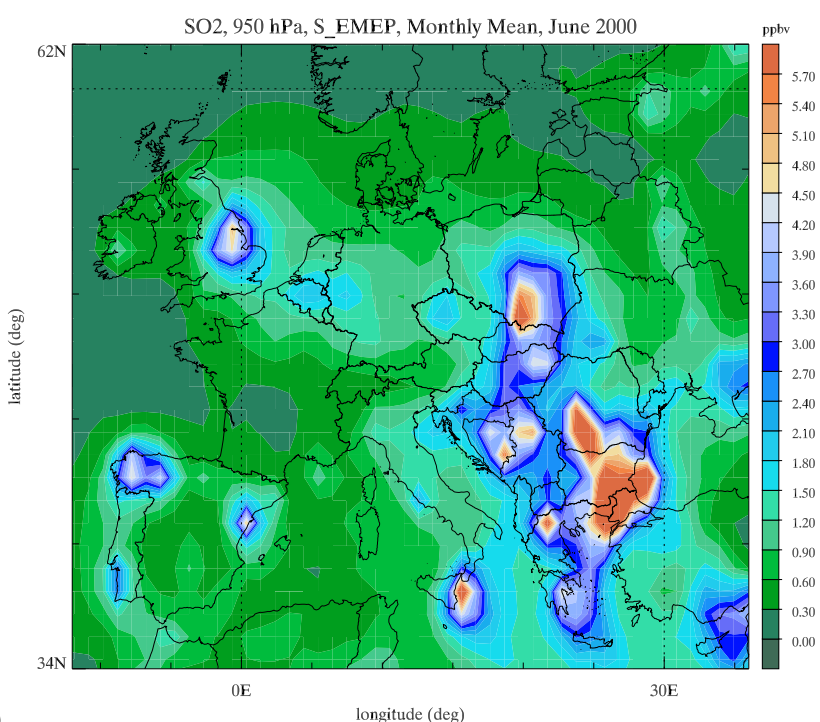

b)

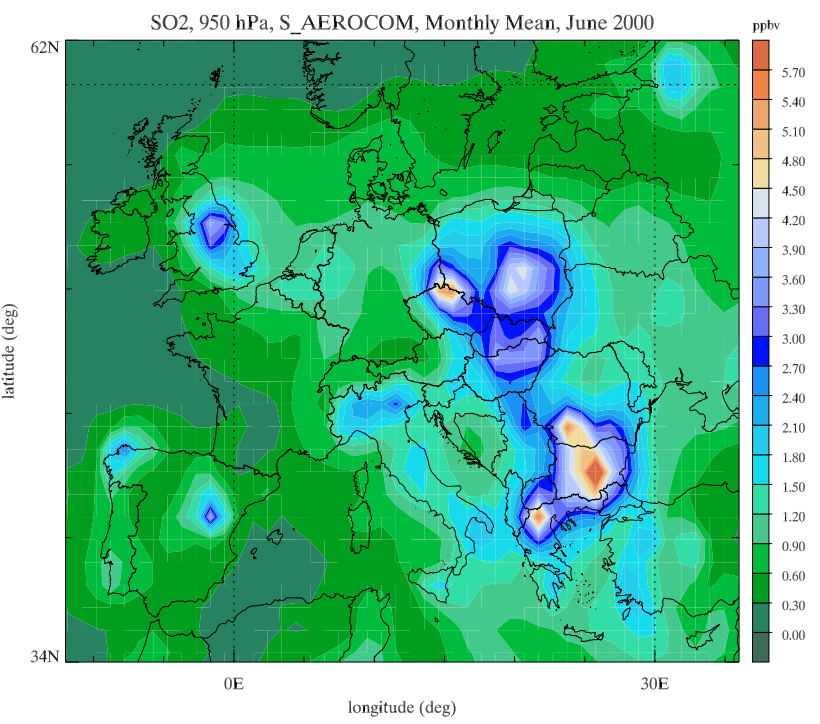

Fig. 2. Monthly $\mathrm{SO}_{2}$ distribution by $\mathrm{S}_{\mathrm{EMEP}}$ and the $\mathrm{S}_{\mathrm{AERO}}$ at surface level (a and $\mathbf{b}$, respectively) and $950 \mathrm{hPa}$ (c and $\mathbf{d}$, respectively) for June 2000.

can be partly explained by the overall higher $(39 \%$, ES Table S6, http://www.atmos-chem-phys.net/6/4287/2006/ acp-6-4287-2006-supplement.pdf) monthly emissions in the AEROCOM inventory compared to EMEP. However, the stations available for comparison with measurements seem heavily biased to Northern Europe, where indeed the spatial difference between the EMEP and AEROCOM inventory seems higher. The vertical distribution plays also here an important role. The monthly mean $\mathrm{NO}_{\mathrm{x}}$ surface concentrations by $\mathrm{S}_{\mathrm{AERO}}$ are up to a factor of 2 higher in the Northern part of Europe, due to higher emissions in the lowest model layer (not shown). The differences in monthly mean $\mathrm{NO}_{\mathrm{x}}$ concentrations at $\pm 500 \mathrm{~m}$ between $\mathrm{S}_{\mathrm{AERO}}$ and $\mathrm{S}_{\mathrm{EMEP}}$ are smaller.
In December, $\mathrm{S}_{\mathrm{EMEP}}$ and $\mathrm{S}_{\mathrm{AERO}} \mathrm{NO}_{\mathrm{x}}$ mean concentrations are closer to the measurements, and are respectively $7 \%$ and $11 \%$ higher (see ES Table S10b, http:/www.atmos-chem-phys.net/6/4287/2006/ acp-6-4287-2006-supplement.pdf). Spatial correlations are 0.76 and 0.79 for $S_{E M E P}$ and $S_{\text {AERO, respectively (based on }}$ 17 stations, 43 rejected).

\subsection{3 $\mathrm{SO}_{4}^{=}$}

Figures 3a-d present the EMEP measured and modelled ( $\mathrm{S}_{\mathrm{EMEP}}$ and $\mathrm{S}_{\mathrm{AERO}}$ ) $\mathrm{SO}_{4}^{=}$concentrations for June and December 2000. Spatial correlation coefficients are comparable for $\mathrm{S}_{\mathrm{EMEP}}(0.66)$ and $\mathrm{S}_{\mathrm{AERO}}(0.65)$ (based on 38 stations 

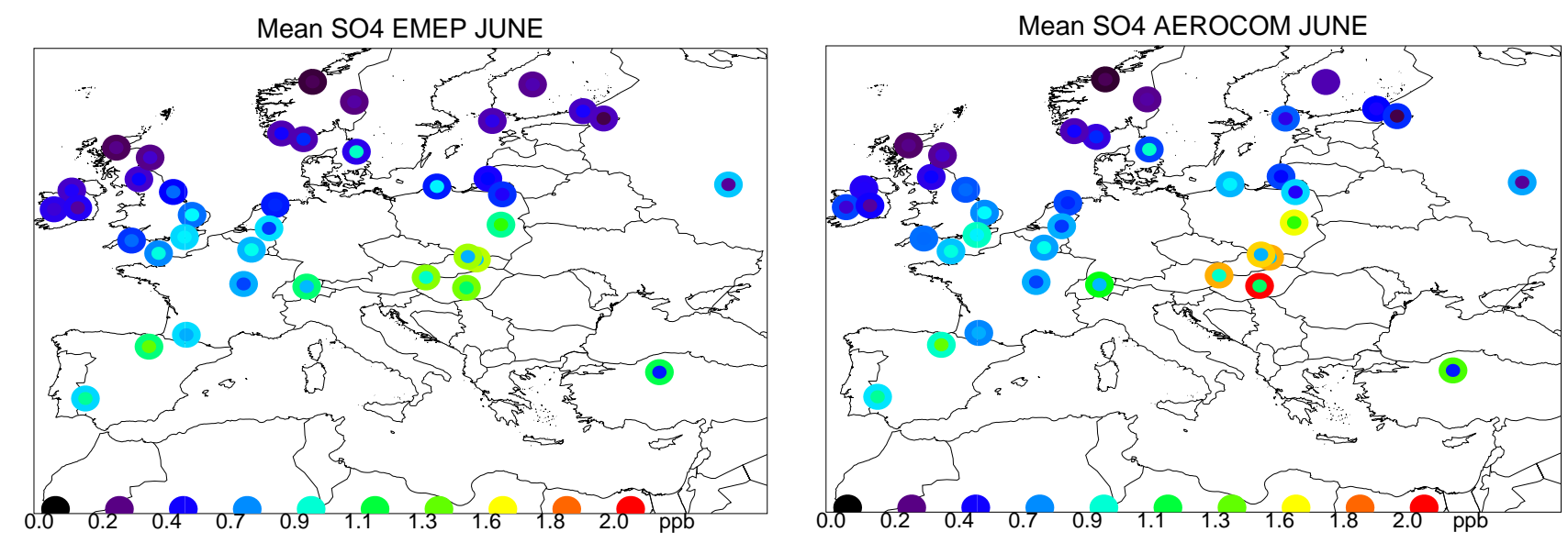

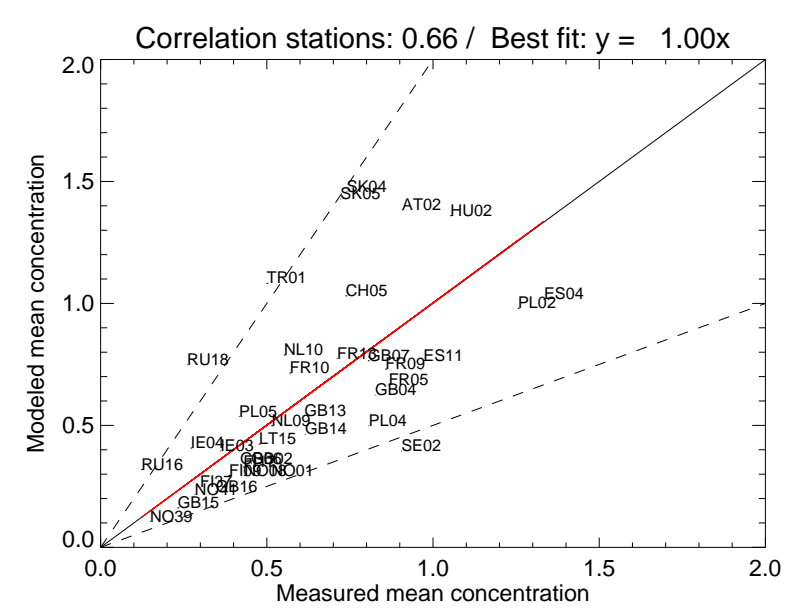

(a)

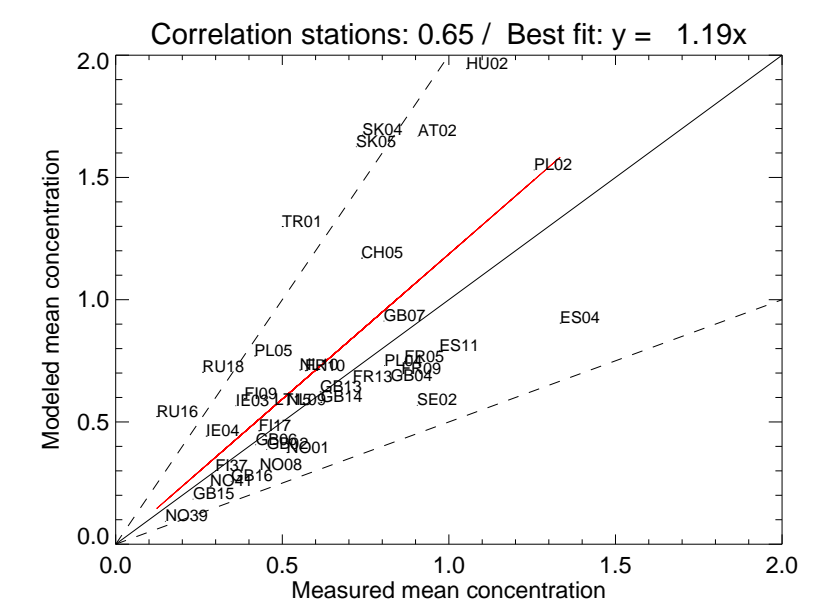

Fig. 3. (a), (b), (c) and (d) are presenting the monthly average measured mixing ratio (inner circle) of $\mathrm{SO}_{4}^{=}$and calculated (outer circle) $\mathrm{SO}_{4}^{=}$by $\mathrm{S}_{\mathrm{EMEP}}$ and $\mathrm{S}_{\mathrm{AERO}}$ for June and December 2000. For reference, the 2:1 and 1:2 lines are shown as the dashed lines, the 1:1 line as solid and the line of best fit is red solid.

used and 33 rejected). The modelled $\mathrm{SO}_{4}^{=}$concentrations by $\mathrm{S}_{\mathrm{EMEP}}$ match the measurements while $\mathrm{S}_{\mathrm{AERO}}$ on average slightly overestimates $\mathrm{SO}_{4}^{=}$aerosol concentrations by $19 \%$. Especially over central Europe (Austria, Hungary, Czech Republic and Poland) significantly higher $\mathrm{SO}_{4}^{=}$concentrations are calculated by $\mathrm{S}_{\mathrm{AERO}}$ than for $\mathrm{S}_{\mathrm{EMEP}}$, which can be attributed to the higher over-all emissions. For December the differences between the two simulations are rather small and both $\mathrm{S}_{\mathrm{EMEP}}$ and $\mathrm{S}_{\mathrm{AERO}}$ underestimate on average the modelled $\mathrm{SO}_{4}^{=}$aerosol concentrations compared with measurement data by as much as a factor 2 (based on 23 stations, 45 rejected). The wintertime underestimation of sulphate concentrations has been observed earlier and is possibly due to a lack of oxidation chemistry in the model (Jeuken, 2000; Kasibhatla et al., 1997). More detailed information in Tables S11a and S11b of the electronic supplement (http://www.atmos-chem-phys.net/6/4287/2006/ acp-6-4287-2006-supplement.pdf).

\subsection{4 $\quad \mathrm{NO}_{3}^{-}$}

Since in summer EMEP measurements have serious measurement artefacts (see Sect. 3) we can only analyse differences between nitrate aerosol computed by $S_{\text {EMEP }}$ and $\mathrm{S}_{\mathrm{AERO}}$ for December. Substantial differences are found for $\mathrm{NO}_{3}^{-}$aerosol: $\mathrm{S}_{\mathrm{AERO}}$ calculates a maximum concentration of $22.1 \mu \mathrm{g} / \mathrm{m} 3$ over Germany, while the $\mathrm{S}_{\mathrm{EMEP}}$ calculated maximum amounts to $9.6 \mu \mathrm{g} / \mathrm{m} 3$. Over Poland $\mathrm{S}_{\mathrm{AERO}}$ calculates $\mathrm{NO}_{3}^{-}$aerosol values of $5 \mu \mathrm{g} / \mathrm{m} 3$, while $\mathrm{S}_{\mathrm{EMEP}}$ calculates $\mathrm{NO}_{3}^{-}$aerosol $<2 \mu \mathrm{g} / \mathrm{m} 3$. The higher $\mathrm{NO}_{3}^{-}$found with the AEROCOM inventory, can be understood from higher $\mathrm{NO}_{\mathrm{x}}(+39 \%)$ and $\mathrm{NH}_{3}(+67 \%)$ emissions in the AEROCOM (taken from EDGAR3.2 database) than in the EMEP inventory.

Reactions (1-4) show how $\mathrm{NO}_{3}^{-}$aerosol formation is related to both $\mathrm{NO}_{x}$ and $\mathrm{NH}_{3}$ emissions:

$$
\mathrm{NO}_{2(\mathrm{~g})}+\mathrm{OH}_{(\mathrm{g})}+\mathrm{M} \rightarrow \mathrm{HNO}_{3(\mathrm{~g})}+\mathrm{M}
$$



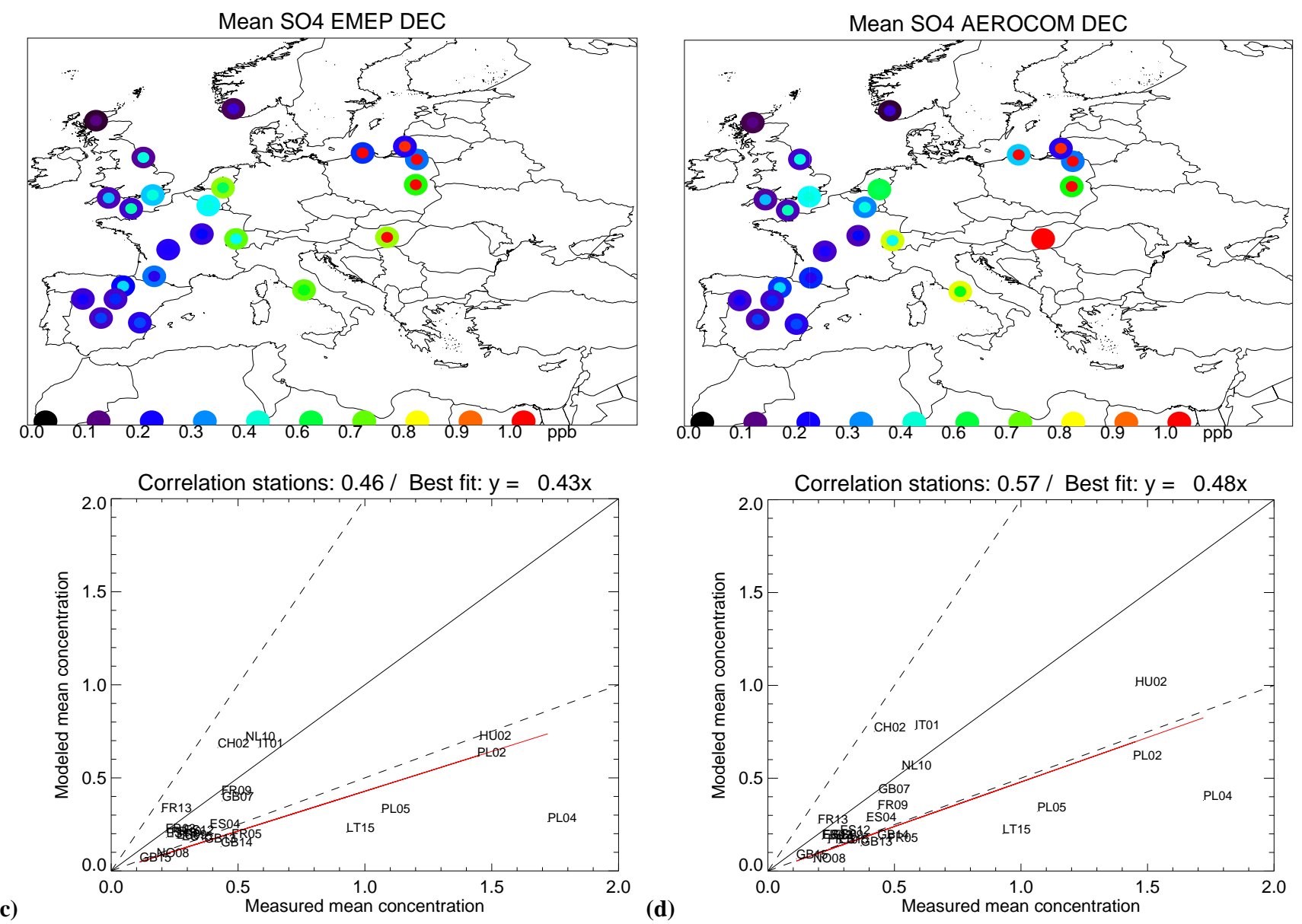

(d)

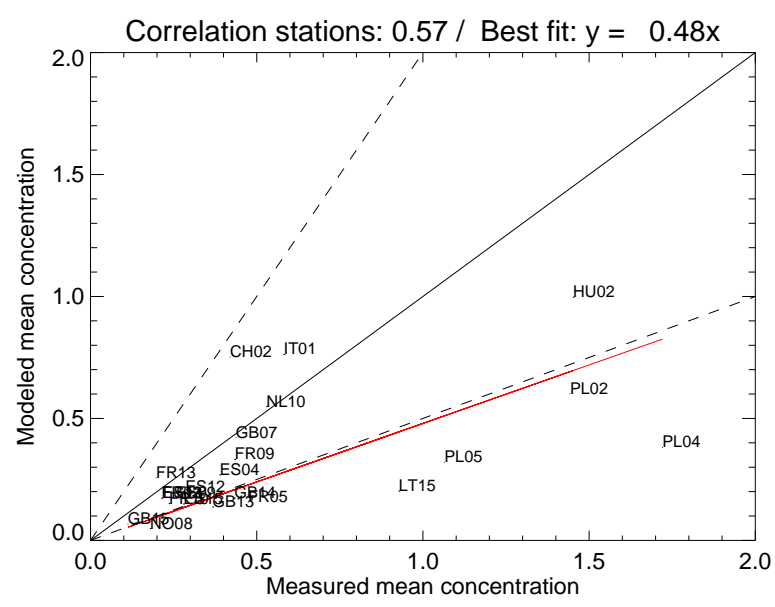

Fig. 3. Continued.

and,

$\mathrm{NO}_{2(\mathrm{~g})}+\mathrm{NO}_{3(\mathrm{~g})} \rightarrow \mathrm{N}_{2} \mathrm{O}_{5}$

The hydrolysis of $\mathrm{N}_{2} \mathrm{O}_{5}$ on wet aerosol surfaces is an important pathway to convert $\mathrm{NO}_{\mathrm{x}}$ into $\mathrm{HNO}_{3}$ (Dentener and Crutzen, 1993; Riemer et al., 2003; Schaap et al., 2003a, b):

$\mathrm{N}_{2} \mathrm{O}_{5(\mathrm{~g})}+\mathrm{H}_{2} \mathrm{O} \rightarrow 2 \mathrm{HNO}_{3}$

$\mathrm{NH}_{3(\mathrm{~g})}+\mathrm{HNO}_{3(\mathrm{~g})} \leftrightarrow \mathrm{NH}_{4} \mathrm{NO}_{3}(\mathrm{aq}, \mathrm{s})$

For December $\mathrm{S}_{\mathrm{EMEP}}$ overestimates measured aerosol nitrate by a factor of 1.37 , and $\mathrm{S}_{\mathrm{AERO}}$ by a factor of 1.62 . Table $S 12$ in the ES (http://www.atmos-chem-phys.net/6/4287/ 2006/acp-6-4287-2006-supplement.pdf) shows that $\mathrm{S}_{\text {AERO }}$ aerosol nitrate concentrations are at all stations higher than those of $\mathrm{S}_{\mathrm{EMEP}}$ (except for PL02). A possible explanation for these differences could be related to higher $\mathrm{NH}_{3}$ emissions (21\% higher in winter) in the AEROCOM than in the EMEP inventory. High spatial correlation coefficients of 0.84 (EMEP) and 0.91 (AEROCOM) are found (based on 6 stations, 15 rejected), indicating that the spatial gradients of the

monthly mean concentrations are relatively well reproduced by the model.

\subsection{5 $\mathrm{NH}_{4}^{+}$}

EMEP reports in many cases the sum of $\mathrm{NH}_{3}$ and $\mathrm{NH}_{4}^{+}$, also called total ammonium $\left(\mathrm{NH}_{\mathrm{x}}\right)$. For these cases we compared measurements to the modelled sum of the two components.

$\mathrm{S}_{\mathrm{EMEP}} \mathrm{NH}_{\mathrm{x}}$ concentrations agree well with measurements for June, and are on average only $4 \%$ higher. In contrast, $\mathrm{S}_{\mathrm{AERO}}$ overestimates $\mathrm{NH}_{\mathrm{x}}$ on average by a factor of 2.0. Analyzing the monthly mean concentrations (ES Table S13a, http://www.atmos-chem-phys.net/6/4287/2006/ acp-6-4287-2006-supplement.pdf), we see that for all stations the values are higher for $\mathrm{S}_{\mathrm{AERO}}$ than for $\mathrm{S}_{\text {EMEP }}$ (based on 20 stations, 17 rejected). The overestimation of $\mathrm{S}_{\text {AERO }}$ can explained by the $67 \%$ higher summer $\mathrm{NH}_{3}$ emissions compared to the EMEP emission inventory. The spatial correlation coefficients are high with 0.81 and 0.80 , respectively.

For December $\mathrm{S}_{\mathrm{AERO}}$ agrees better with the measurements, and on average $\mathrm{S}_{\mathrm{AERO}}$ and $\mathrm{S}_{\mathrm{EMEP}}$ underestimate the 
Table 1. Monthly mean BC and POM concentrations $\left(\mu \mathrm{g} / \mathrm{m}^{3}\right)$ for all the stations calculated by $\mathrm{S}_{\text {EMEP }}$ and $\mathrm{S}_{\mathrm{AERO}}$, together with EMEP measurement data for December 2002 and June 2003.

\begin{tabular}{|c|c|c|c|c|c|c|c|c|c|c|c|c|c|c|}
\hline & \multicolumn{14}{|c|}{$\mathrm{BC}$} \\
\hline & $\begin{array}{l}\text { EMEP } \\
\mu \mathrm{g} / \mathrm{m}^{3}\end{array}$ & 2002 & Dec & $\begin{array}{l}\mathrm{S}_{\text {EMEP }} \\
\mu \mathrm{g} / \mathrm{m}^{3}\end{array}$ & 2000 & Dec & $\begin{array}{l}\mathrm{S}_{\mathrm{AERO}} \\
\mu \mathrm{g} / \mathrm{m}^{3}\end{array}$ & 2000 & Dec & $\begin{array}{l}\text { EMEP } \\
\mu \mathrm{g} / \mathrm{m}^{3}\end{array}$ & 2003 & June & $\begin{array}{l}\text { SEMEP } 2000 \text { June } \\
\mu \mathrm{g} / \mathrm{m}^{3}\end{array}$ & $\begin{array}{l}\mathrm{S}_{\mathrm{AERO}} 2000 \text { June } \\
\mu \mathrm{g} / \mathrm{m}^{3}\end{array}$ \\
\hline \multirow[t]{3}{*}{ Average } & 1.25 & & & 0.47 & & & 0.51 & & & 0.64 & & & 0.30 & 0.47 \\
\hline & \multicolumn{14}{|c|}{ POM } \\
\hline & $\begin{array}{l}\text { EMEP } \\
\mu \mathrm{g} / \mathrm{m}^{3}\end{array}$ & 2002 & Dec & $\begin{array}{l}\mathrm{S}_{\mathrm{EMEP}} \\
\mu \mathrm{g} / \mathrm{m}^{3}\end{array}$ & 2000 & Dec & $\begin{array}{l}\mathrm{S}_{\mathrm{AERO}} \\
\mu \mathrm{g} / \mathrm{m}^{3}\end{array}$ & 2000 & Dec & $\begin{array}{l}\text { EMEP } \\
\mu \mathrm{g} / \mathrm{m}^{3}\end{array}$ & 2003 & June & $\begin{array}{l}\text { SEMEP } 2000 \text { June } \\
\mu \mathrm{g} / \mathrm{m}^{3}\end{array}$ & $\begin{array}{l}\mathrm{S}_{\mathrm{AERO}} 2000 \\
\mu \mathrm{g} / \mathrm{m}^{3}\end{array}$ \\
\hline Average & 5.74 & & & 0.71 & & & 0.88 & & & 4.85 & & & 0.62 & 1.67 \\
\hline
\end{tabular}

measured values with $7 \%$, and $26 \%$, respectively (based on 12 stations, 26 rejected). More detailed information per station in ES Table S13b .

\subsubsection{BC}

Unfortunately we have only one station (Ispra, Italy) to our disposal for comparison with black carbon (BC) simulations for the year 2000 (http://ccu.jrc.it/). Modelled mean $\mathrm{BC}$ concentration of $1.37 \mu \mathrm{g} / \mathrm{m}^{3}$ computed by $\mathrm{S}_{\mathrm{AERO}}$ is about $45 \%$ higher than the measured mean of $0.93 \mu \mathrm{g} / \mathrm{m}^{3}$ for June. In the same month, $\mathrm{S}_{\mathrm{EMEP}}$ underestimate $\mathrm{BC}$ by $33 \%\left(0.62 \mu \mathrm{g} / \mathrm{m}^{3}\right)$. In December, the concentrations are $2.17 \mu \mathrm{g} / \mathrm{m}^{3}, 1.42 \mu \mathrm{g} / \mathrm{m}^{3}$, and $1.90 \mu \mathrm{g} / \mathrm{m}^{3}$ for $\mathrm{S}_{\text {AERO, }} \mathrm{S}_{\text {EMEP }}$ and measurements, respectively. More BC measurements are available for 2002 and 2003. However, a quantitative comparison with the 2000 simulations is difficult since the yearto-year variations can be large. For instance, EMEP measured in Ispra for June 2002 a monthly mean of $1.38 \mu \mathrm{g} / \mathrm{m}^{3}$, compared to $0.93 \mu \mathrm{g} / \mathrm{m}^{3}$ in June 2000. Nevertheless, to give an qualitative impression we present in Table 1 the average of the calculated BC concentrations of the 9 stations by $S_{\mathrm{EMEP}}$ and $\mathrm{S}_{\mathrm{AERO}}$ and the EMEP measurement data for December 2002 and June 2003. BC concentrations for each station are given in ES Table S14a. For some stations the model corresponds very well with the measurements; in December with AT02, in June 2003 with AT02, DE02, FI17 and SE12. However, at the majority of the stations the model underestimates BC concentrations, sometimes up to a factor of 7 (PT01). While the latter value may be influenced by wood burning for residential heating purposes. A possible explanation for these underestimations may be related to the uncertainties in the emission factors for $\mathrm{BC}$ in emission inventories, and unaccounted sources of $\mathrm{BC}$ which contribute to underestimation of $\mathrm{BC}$ in the emission inventories, as discussed by Schaap et al. (2004).

\subsubsection{POM}

Also for POM we have only one station (Ispra, Italy) to our disposal for model comparison for the year 2000. In June, the monthly mean POM concentration by $\mathrm{S}_{\text {AERO }}\left(2.35 \mu \mathrm{g} / \mathrm{m}^{3}\right)$ is a factor of three higher than by $\mathrm{S}_{\text {EMEP }}\left(0.70 \mu \mathrm{g} / \mathrm{m}^{3}\right)$, because SOA emissions are included in the AEROCOM emission inventory, while for EMEP not. However POM by $\mathrm{S}_{\mathrm{AERO}}$ is still underestimated when compared to the measured monthly mean $\left(3.00 \mu \mathrm{g} / \mathrm{m}^{3}\right)$. In December the modelled monthly mean POM concentrations for $\mathrm{S}_{\mathrm{AERO}}$ and $S_{\text {EMEP }}$ are the same $\left(1.43 \mu \mathrm{g} / \mathrm{m}^{3}\right)$, but heavily underestimated when compared to the measured monthly mean $\left(9.59 \mu \mathrm{g} / \mathrm{m}^{3}\right)$. More POM measurements are available for 2002 and 2003. As described above, a quantitative comparison with 2000 calculations can be difficult due to year-toyear variations. Also given in Table 1 is the average of the calculated POM concentrations of the 9 stations by $S_{\text {EMEP }}$ and $\mathrm{S}_{\mathrm{AERO}}$ and the EMEP measurement data for December 2002 and June 2003. POM concentrations for each station are given in ES Table S15 (http://www.atmos-chem-phys. net/6/4287/2006/acp-6-4287-2006-supplement.pdf).

In June 2000, POM concentrations by $S_{\text {AERO are for any }}$ station higher than by $\mathrm{S}_{\mathrm{EMEP}}$, and agree better with measurement 2003 data, but still underestimated up to a factor of 5. In December the differences between $S_{\text {EMEP }}$ and $S_{A E R O}$ are smaller and are for all the stations underestimated when compared to measurements.

\subsection{Case study of AOD over Europe on 11 June 2000}

In this section we demonstrate the ability of our model to represent the spatial distribution of aerosol as seen from the MODIS satellite, by MODIS AOD retrieval for 11 June 2000. This specific event also allows evaluation of the factors determining spatial differences resulting from the use of the two inventories. This specific day was chosen, since it represents a relatively cloud-free day throughout especially in central and eastern Europe, with heterogeneous contributions of desert dust intrusions in southern Europe and mixed pollution and dust in central and northern Europe.

The MODIS retrieved AOD is displayed in Fig. 4a. Three regions of high AOD (0.6-0.9) are observed: Southern Italy/Balkans, the Czech Republic/Romania, and North East 
(a)
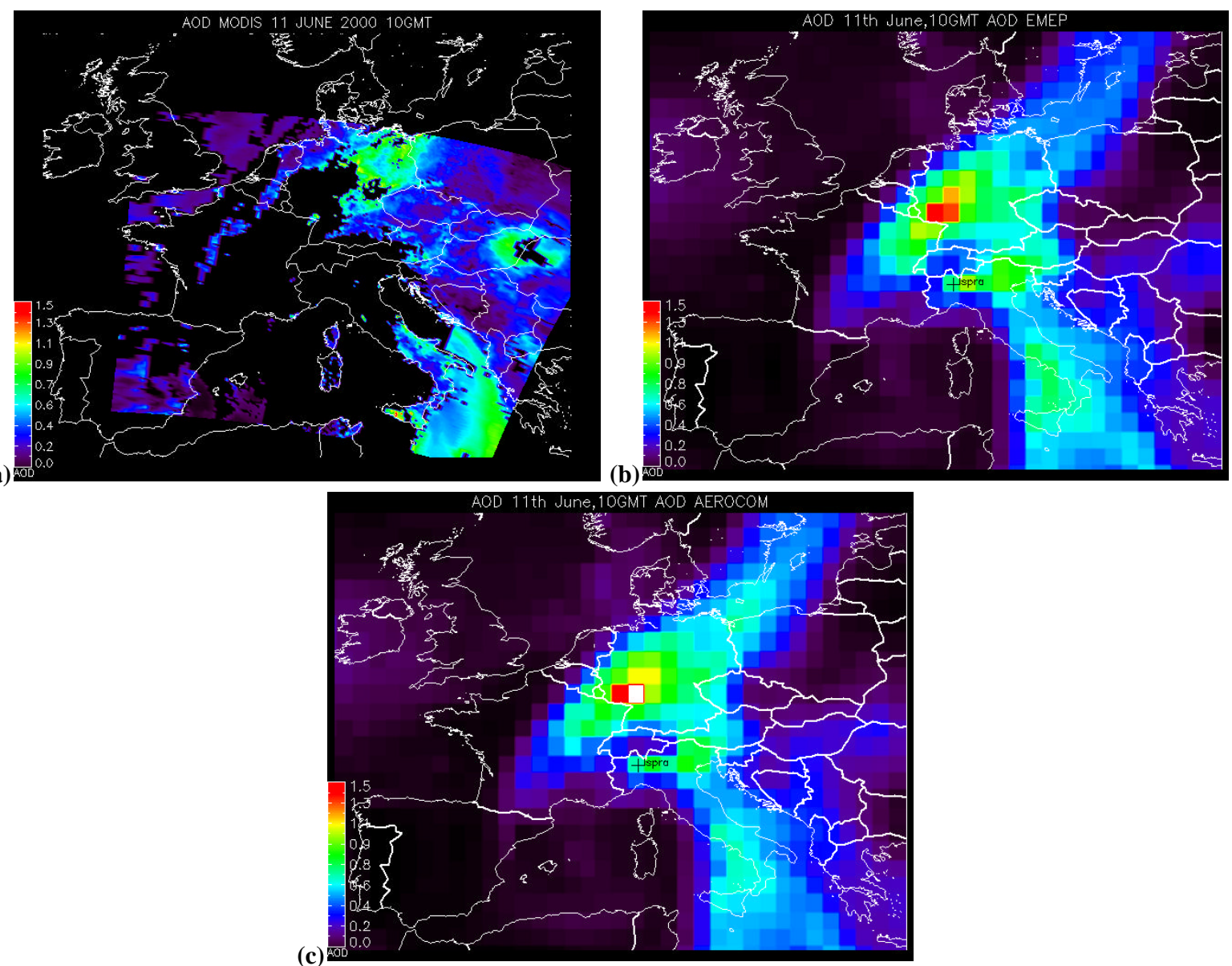

Fig. 4. AOD over Europe for 11 June 10:00 GMT, 2000 by MODIS (a), AOD by $\mathrm{S}_{\mathrm{EMEP}}$ (b) and $\mathrm{S}$ AERO (c). White colours represent AOD values larger than 1.5. Note that for aerosol equilibrium calculations an upper limit for $R H 95 \%$ was used. No cloud masking was applied to model results.

MODIS MOD04_L2.A2000163.1035.004.2002365174903.hdf, variable optical_Depth_Land_And_Ocean is used.

Germany. Elsewhere the retrieved AOD was of the order of $0.1-0.2$. It should be noted that in other parts of Europe no aerosol was reported, due to detection of clouds by the MODIS cloud screening algorithm. Over the southern part of Italy, MODIS registers small and large Angstrom coefficients, indicating that both coarse (dust) and fine particles are found in this region. Over the eastern part of Europe MODIS registers large Angstrom coefficients, which is typical for small particles, e.g. inorganic sulphate- and nitrate aerosols.

With our CTM we can compare these observations with model calculated AOD, but additionally, with the model we are able to evaluate the contributions to AOD of single aerosol components. Figures $4 \mathrm{~b}$ and $\mathrm{c}$ depicts the computed AOD distribution over Europe for 11 June 2000, 10:00 GMT for $\mathrm{S}_{\mathrm{EMEP}}$ and $\mathrm{S}_{\mathrm{AERO}}$, respectively. We note here that the AOD calculations are based on the relative humidity in the cloud free part of the $1^{\circ} \times 1^{\circ}$ model grid-box (diagnosed from the grid-box average $R H$ ) and that the $R H$ should not exceed
95\%. However, clouds are not "masked" in our model calculations. To avoid calculations of highly uncertain $R H$ in regions with almost complete cloud cover we discard the regions with ECMWF cloud cover larger than $90 \%$. The distribution of AOD over Europe as calculated with the two inventories is very similar: maximum AOD values of 1.4 ( $\left.\mathrm{S}_{\mathrm{EMEP}}\right)$ and 1.6 ( $\left.\mathrm{S}_{\mathrm{AERO}}\right)$ are found over the western part of Germany, and bands of high AOD (0.6-0.9) are calculated over almost entire Germany, Austria, and Italy. Clean air travelling behind a frontal system in the western part of Europe, England, Denmark, the Netherlands, Belgium, France, and Spain is associated with AOD smaller than 0.2. The high model AOD given by the two model simulations agrees very well with MODIS over Germany and Italy, but the high AOD retrieved over the Czech Republic/Romania is underestimated by the two model simulations. The model calculated AOD over Western Europe seems somewhat lower than the retrieved values. 
Table 2. Averaged AOD values together with the corresponding correlation coefficients for June and December 2000 for all the AERONET stations used in this work. The values are based on monthly mean AOD calculated by TM5 with the EMEP emission inventory and the AEROCOM emission inventory for each station.

\begin{tabular}{llllll}
\hline & $\begin{array}{l}\text { Monthly mean }+ \\
\text { sdev AOD S }\end{array}$ & r. & $\begin{array}{l}\text { Monthly mean }+ \\
\text { sdev AOD S }\end{array}$ & r. & $\begin{array}{l}\text { Monthly mean }+ \\
\text { sdev AOD AERONET }\end{array}$ \\
\hline June average & $0.15 \pm 0.16$ & 0.22 & $0.16 \pm 0.14$ & 0.22 & $0.19 \pm 0.11$ \\
December average & $0.08 \pm 0.06$ & 0.05 & $0.07 \pm 0.05$ & 0.02 & $0.12 \pm 0.06$ \\
\hline
\end{tabular}

How do individual components contribute to the AOD?

A desegregation of individual components indicates that especially in the vicinity of Southern Italy, dust contributes with 0.15 (or $25 \%$ ) to the AOD, which is in agreement with the MODIS observed Angstrom coefficients. In Northern Europe dust contributes with 0.05 to the computed AOD of 0.9. There the high computed AOD is caused by elevated concentrations of inorganic aerosols $\left(\mathrm{SO}_{4}^{-}, \mathrm{NO}_{3}^{-}\right.$and $\mathrm{NH}_{4}^{+}$) and associated aerosol water (aerosol water makes up to $70 \%$ of the total aerosol mass over this area). The presence of small particulate inorganic aerosols in this area is found back in the Angstrom coefficients retrieved by MODIS which range from 2.5 to 4 . According to the ECWMF meteorological data underlying our model, high $R H(>90 \%)$ and cloud cover around $70 \%$ prevail in the western part of Germany and high AOD is calculated due to the uptake of large amount of water by the inorganic aerosols. MODIS does not register AOD at all for this area, due to the reported presence of warm clouds. While this is consistent with the ECMWF meteorology, MODIS does probably often discard aerosol in the vicinity of regions with partial cloud cover and high $R H$.

As outlined in the previous section, the use of the AEROCOM emissions inventory leads to higher surface concentrations of $\mathrm{SO}_{4}^{=}$and $\mathrm{NO}_{3}^{-}$, because summertime emissions are higher. These differences are partially reflected in the calculated AOD. As mentioned above, the AOD geographical patterns of $\mathrm{S}_{\mathrm{AERO}}$ and $\mathrm{S}_{\mathrm{EMEP}}$ are similar, but over the Baltic Sea AOD difference up to 0.4 are calculated, due to higher $\mathrm{SO}_{4}^{=}$concentrations over this area. In ES Table S11a (http://www.atmos-chem-phys.net/6/4287/2006/ acp-6-4287-2006-supplement.pdf) we see that higher $\mathrm{SO}_{4}^{=}$ concentrations are calculated by $\mathrm{S}_{\mathrm{AERO}}$ than by $\mathrm{S}_{\mathrm{EMEP}}$ (up to a factor of 2) for the Finish, Swedish and Lithuanian stations. Over the southern part of Italy, higher AOD values are calculated by $\mathrm{S}_{\mathrm{EMEP}}$, up to 0.2 difference. For this area $\mathrm{S}_{\text {EMEP }}$ calculates higher $\mathrm{SO}_{4}^{=}$concentrations than $\mathrm{S}_{\mathrm{AERO}}$, up to $9 \mu \mathrm{g} / \mathrm{m}^{3} \mathrm{SO}_{4}^{=}$difference.

In the next section we will compare the calculated AOD values to AERONET measurements.

\subsection{Comparison of modelled AOD with AERONET}

In this section we compare modelled AOD with the retrieved AOD at a selected number of AERONET stations. While the geographic coverage of AERONET is rather limited as compared to the satellite data described in the previous section, we use the much higher time resolution to evaluate the temporal evolution of AOD in our model. To ensure monthly representativity we select for this comparison AERONET stations for which more than 50 observations per month are reported; i.e. for June 9 stations and for December only 6. An observation may represent a time span ranging from a few minutes to $15 \mathrm{~min}$. The model output was sampled at station location at an hourly frequency. Table 2 present the average of the observed and computed ( $\mathrm{S}_{\mathrm{EMEP}}$ and $\mathrm{S}_{\mathrm{AERO}}$ ) monthly mean AOD for all stations, together with the temporal correlation for June and December. In ES Tables S16 and S17 (http://www.atmos-chem-phys. net/6/4287/2006/acp-6-4287-2006-supplement.pdf) the observed and computed ( $\mathrm{S}_{\mathrm{EMEP}}$ and $\mathrm{S}_{\mathrm{AERO}}$ ) monthly mean AOD and their temporal correlation for each station is given for June and December 2000, respectively. Correlations between model and measurement are rather low and range for individual stations between -0.04 and 0.52 . On average the June AOD of $\mathrm{S}_{\mathrm{EMEP}}$ is $5 \%$ lower than the $\mathrm{S}_{\mathrm{AERO}} \mathrm{AOD}$ and both simulations underestimate AERONET AOD by on average $30 \%$. Also for December both simulations underestimate the AERONET AOD by $35 \%$. To demonstrate the factors contributing to temporal variability we now focus in more detail on 5 stations in June (Figs. 5a-e) with a relatively large measurement records, and a widely varying geographic location: (i) El Arenosillo is a coastal site in Southern Spain (ii) Moldova is located in Eastern Europe, (iii) IMC Oristano is located on Sardinia in the Mediterranean Sea, (iv) Ispra is located at the foothills of the Alps in Northern Italy and (v) Avignon is located in the South/East part of France. Apart from the calculated AOD, we also show the contribution of the dominant aerosol component to AOD.

Modelled dust had a substantial contribution to the total AOD in El Arenosillo (Fig. 5a) around the 4, 9, 17-19, 2527 June. Indeed on these days high AOD were observed by AERONET (up to 0.55 on 26 June) and AERONET Angstrom coefficients ranged from 0.4-1.5, indicating the 
presence of large dust particles. The monthly mean AOD values calculated for both the emission inventories $(0.09 \pm 0.11)$ are in line with the monthly mean AOD observed by AERONET $0.12 \pm 0.07$ (ES Table S16). Temporal correlation coefficients of simulation and measurements are about 0.5 . The high correlation is clearly caused by a correct timing of the dust events by the model and similar in both simulations.

For IMC Oristano (Fig. 5b) we see again the large influence of dust on AOD. AERONET AOD values goes up $(>0.2)$ on days where the model calculates high dust loads. This is confirmed by the small Angstrom coefficients retrieved for the days with high dust events (not shown). However, the high observed and modelled AOD in the period 5-9 June seems unrelated to dust and caused by a large contribution of inorganic aerosol. Calculated monthly mean AOD values are about 0.15 and in agreement with AERONET retrieved AOD of 0.15. The rather low time correlation appears to be the result of large diurnal variations in measured AOD which are not reproduced by the model.

At Ispra, two pollution events are visible in the measured AOD: 3-6 and 9-13 June.

The first pollution period could be an error in the cloud screening algorithm (G. Zibordi, personal communication, 2005) and is therefore neglected. However, consistent with observations, from the 9 to 13 June the model calculates a large contribution of inorganic aerosol to the total AOD (Fig. 5c). Note that AERONET reports cloud cover during parts of this event. We have seen in Sect. 4.2 that the model calculates high $\mathrm{SO}_{4}^{=}$aerosol concentrations for this area (up to $20 \mu \mathrm{g} / \mathrm{m}^{3}$ ). During this episode, high relative humidity $(\mathrm{RH})$ values of $76 \%$ were measured at the EMEP measurement station. ECMWF meteorological data used by TM5 showed average $R H$ values of $82 \%$ for the same 5 day period. These high $R H$ values in combination with high inorganic aerosol loads increase the uptake of water by aerosol, and hence AOD.

At Moldova (Fig. 5d), inorganic aerosol impacts the total AOD in a similar way. High concentrations of inorganic aerosol together with high relative humidity cause high AOD values by AERONET and the model. One exception is encountered on 21 June when the model calculates high AOD values $(0.5)$ due to the presence of inorganic aerosol and high $R H$ values (90\%), where AERONET observes low AOD $(0.08)$ values. The model calculates a monthly mean AOD of about 0.18 , which is close to the monthly mean observed by AERONET.

The high AOD values calculated at Avignon (Fig. 5e) are caused by the high relative humidities together with high concentrations of inorganic aerosol, leading to AOD values up to 0.8 . The model calculates a monthly mean AOD of about 0.10 , which is about $30 \%$ lower than the monthly mean observed by AERONET (0.15).
Noticeable in all comparisons is the relatively small difference between the $S_{\text {EMEP }}$ and $S_{\text {AERO }}$ AOD results, compared to the AERONET observed AOD. Apparently, the differences observed close to the surface, quickly become smaller (or are even compensated) at some height, as was also observed in Figs. 2c and d for $\mathrm{SO}_{2}$ and $\mathrm{NO}_{\mathrm{x}}$. The height distribution of the emissions is obviously a less important factor for AOD values than for surface concentrations.

\subsection{Temporal distribution of emissions}

In the previous sections we evaluated the overall impact of the EMEP and AEROCOM emission inventories on aerosol (precursor) and AOD calculations. In this section we evaluate uncertainties arising from the neglect of the temporal variations of the emissions. Apart from seasonal variations in emissions, this includes also variations on shorter timescales, like diurnal, and day of week variations. Outside Europe and the USA this information is often not available, which is one of the reasons that these variations are normally not included in global emission inventories of anthropogenic emissions. To study the role of temporal variation of emissions over Europe, we performed two additional simulations. We compared $\mathrm{S}_{\mathrm{EMEP}}$ (including temporal variation factors) with $\mathrm{S}_{\mathrm{EMEP}_{-} \mathrm{c}}$, which uses constant hourly and daily emissions. In SEMEP_c however, we retained the seasonal information on emissions. The importance of these seasonal variations was already shown in ES Table S6 (http://www.atmos-chem-phys.net/6/4287/ 2006/acp-6-4287-2006-supplement.pdf) where AEROCOM emissions in June appeared to be higher due to a lack in seasonal variation. In Sect. 4.4.2 we assess this issue again by comparing a simulation without seasonal variations (S EMEP_c_annual $_{\text {) with }} \mathrm{S}_{\text {EMEP_c }}$.

\subsubsection{The impact of daily and weekly emission variations}

For short-lived species, like $\mathrm{NO}_{\mathrm{x}}$ and $\mathrm{NH}_{3}$, the short-term emission fluctuations are quite important. To illustrate this we show in Figs. 6a and $b$ the temporal evolution of $\mathrm{NO}_{2}$ and $\mathrm{NH}_{3}$ emissions, and the corresponding $\mathrm{S}_{\mathrm{EMEP}}$ and $\mathrm{S}_{\text {EMEP_c }}$ concentrations for Ispra $\left(8.6^{\circ} \mathrm{E}, 45.8^{\circ} \mathrm{N}\right)$ for the period $1-8$ June. At Ispra, the $\mathrm{NO}_{2}$ emission variations are dominated by a daily cycle, and the influence of weekend/working day emission variation is small, about $10 \%$. There appears a strong co-variance of night-time stability and accumulation of $\mathrm{NO}_{2}$ emission in $\mathrm{S}_{\text {EMEP_c }}$ in the beginning of the week, dominated by fair weather conditions. During the second half of the week the differences are smaller because unstable meteorological conditions caused more vigorous mixing and advective transport. Similarly, $\mathrm{NH}_{3}$ accumulation appeared in SEMEP_c during the first part of the week, but not in the second (Fig. 6b). In December (not shown) these day-night differences in concentrations are much less, since the daynight contrast in atmospheric stability is smaller. $\mathrm{NH}_{3}$ and 


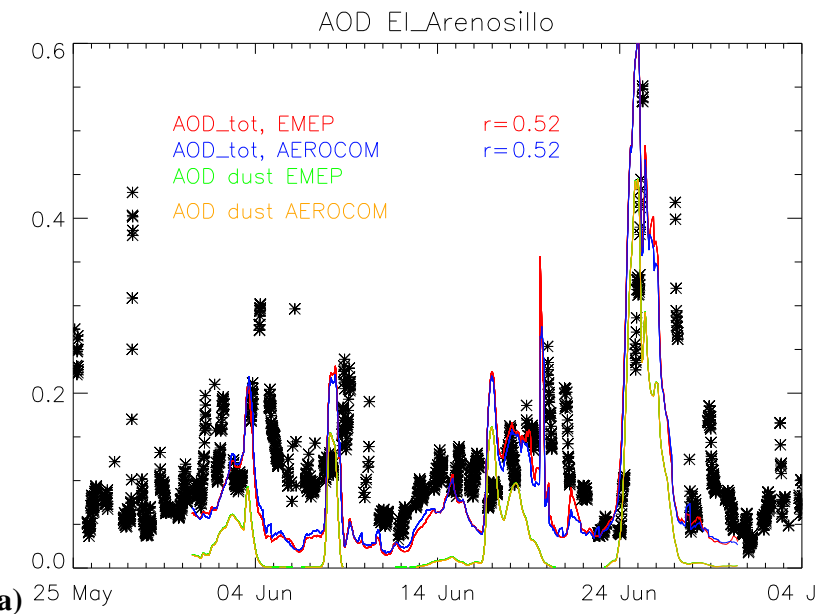

(a)

ul (b)
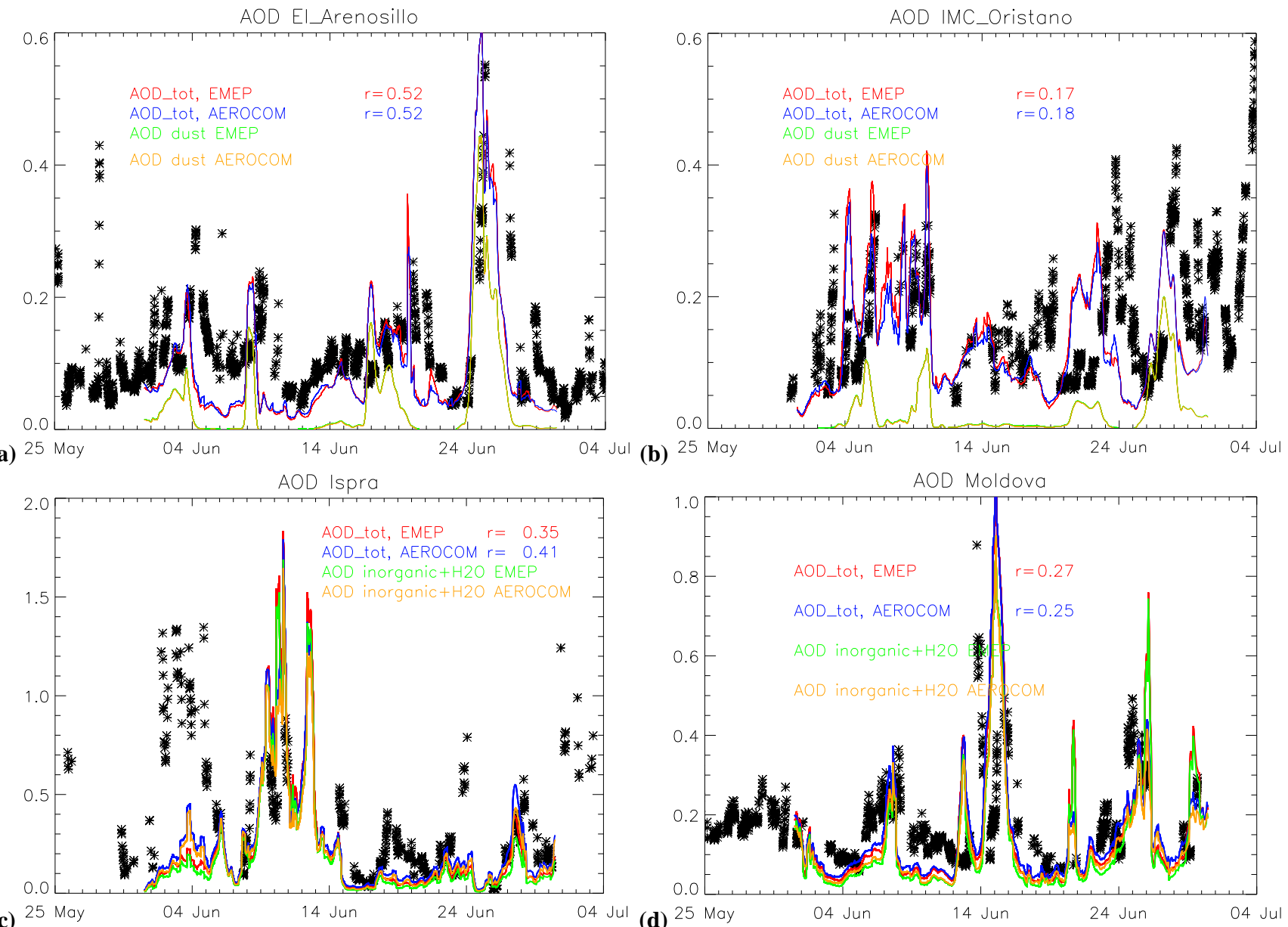

(c)

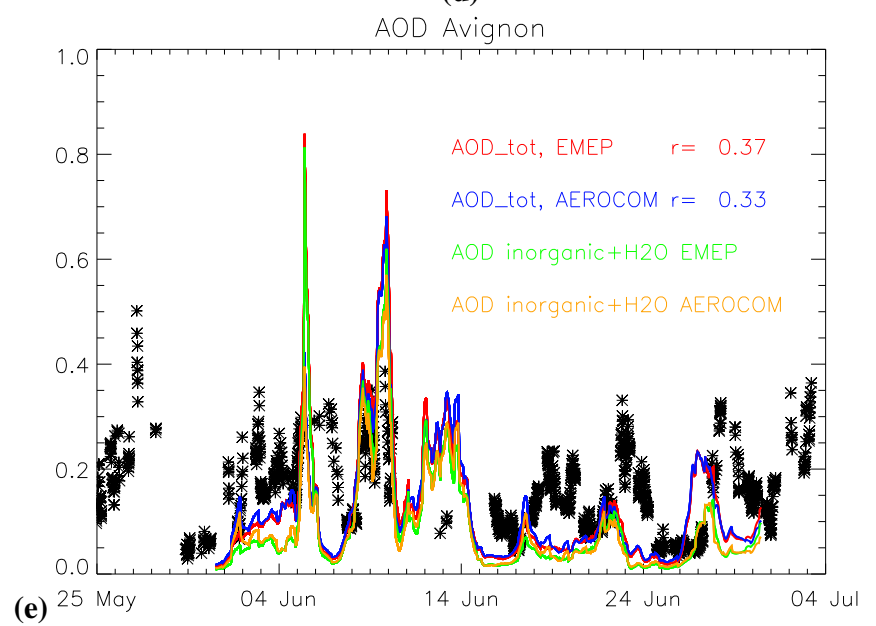

Fig. 5. Total AOD of TM5 with EMEP emission inventory (red line) and AEROCOM emission inventory (blue line) and AERONET AOD (black stars), together with the AOD of the component which has the largest contribution to the total AOD, for El Arenosillo (a), IMC_Oristano (b), Ispra (c), Moldova (d) and Avignon (e). Brown presents AOD by dust for AEROCOM (a, b) or inorganic aerosol and the associated water for $(c-e)$. Green AOD by dust $(a, b)$ or by inorganic aerosol and the associated aerosol water for (c-e).

$\mathrm{NO}_{\mathrm{x}}$ concentrations by $\mathrm{S}_{\mathrm{EMEP}}$ are in general lower than by $\mathrm{S}_{\mathrm{EMEP} \_\mathrm{c}}$.
We analyse in ES Table S18 the significance of this comparing the modelled concentrations for the simulations with and without the temporal distribution, and when possible also 

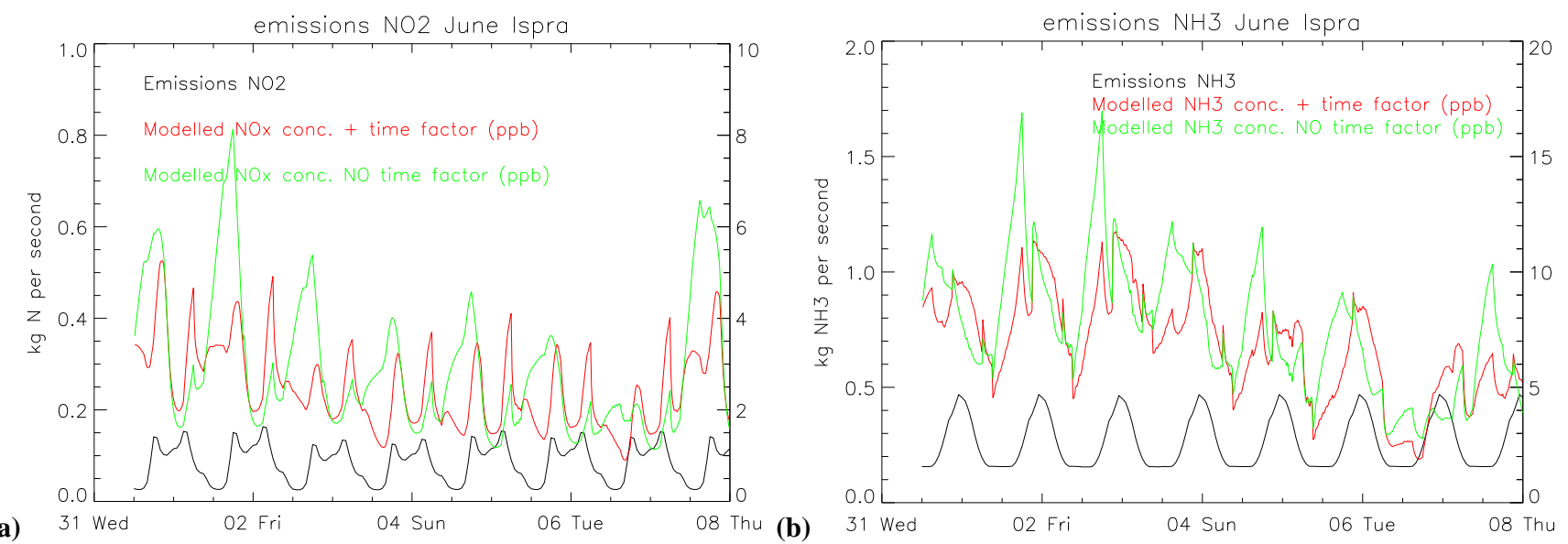

Fig. 6. The temporal distribution of $\mathrm{NO}_{2}$ (a) and $\mathrm{NH}_{3}$ (b) emissions together with the modelled concentrations with and without temporal variation, for Ispra, June 2000.

Table 3. Averaged concentrations and the corresponding standard deviation of all stations of the aerosol precursor gases $\mathrm{NH}_{3}$ and $\mathrm{NO}_{\mathrm{x}}$ for which the correlation coefficient for calculated $\mathrm{NO}_{\mathrm{x}}$ between $\mathrm{S}_{\mathrm{EMEP}}$ and $\mathrm{S}_{\mathrm{EMEP}} \mathrm{c}$ in June is $<0.8$.

\begin{tabular}{llllllll}
\hline & \multicolumn{3}{c}{$\mathrm{NH}_{3} \mathrm{ppb}$} & \multicolumn{5}{c}{$\mathrm{NO}_{\mathrm{x}} \mathrm{ppb}$} \\
& $\mathrm{S}_{\text {EMEP }}$ & $\mathrm{S}_{\text {EMEP_C }}$ & $\mathrm{r}$ & $\mathrm{S}_{\text {EMEP }}$ & $\mathrm{S}_{\text {EMEP_C }}$ & $\mathrm{r}$ & EMEP data \\
\hline June average & $3.84 \pm 2.07$ & $3.99 \pm 2.26$ & 0.78 & $4.85 \pm 1.68$ & $5.11 \pm 1.72$ & 0.56 & $4.71 \pm 1.70$ \\
$\begin{array}{l}\text { December aver- } \\
\text { age }\end{array}$ & $2.60 \pm 1.85$ & $2.54 \pm 1.70$ & 0.85 & $9.37 \pm 6.40$ & $9.36 \pm 6.22$ & 0.94 & $8.53 \pm 4.09$ \\
\hline
\end{tabular}

with available observations. We analyzed the 14 EMEP measurement locations (44 rejected), for which the deviation between the two simulations was found to be important (i.e. nearby regions of high emissions). The correlation coefficient for calculated $\mathrm{NO}_{\mathrm{x}}$ between $\mathrm{S}_{\mathrm{EMEP}}$ and $\mathrm{S}_{\text {EMEP_c }}$ for these 14 stations in June is $<0.8$, indicating the importance of the daily and weekly distribution of the $\mathrm{NO}_{\mathrm{x}}$ emissions. The average concentrations of $\mathrm{NH}_{3}$ and $\mathrm{NO}_{\mathrm{x}}$ for all the stations by $\mathrm{S}_{\mathrm{EMEP}}$ and $\mathrm{S}_{\mathrm{EMEP} \_\mathrm{c}}$ for June and December is given in Table 3.

For June the monthly averaged $\mathrm{NH}_{3}$ and $\mathrm{NO}_{\mathrm{x}}$ concentrations are on average and in almost all cases somewhat lower when daily and weekly emission variations are taken into account, up to $13 \%$ for $\mathrm{NO}_{\mathrm{x}}$ and $25 \%$ for $\mathrm{NH}_{3}$. Correlation coefficients of hourly modelled concentrations at the selected locations are between $0.29-0.74$ for $\mathrm{NO}_{\mathrm{x}}$, and between 0.650.89 for $\mathrm{NH}_{3}$ (ES Table S18a, http://www.atmos-chem-phys. net/6/4287/2006/acp-6-4287-2006-supplement.pdf). The results of the modelled $\mathrm{NO}_{\mathrm{x}}$ concentrations of both simulations agree on average very well with both observations.

We have very few representative $\mathrm{NH}_{3}$ measurement data available; e.g. for $\mathrm{NH}_{3}$ in the Netherlands (NL10) calculated by $S_{\text {EMEP }}$ is lower ( $\left.5.90 \mathrm{ppb}\right)$ than by $\mathrm{S}_{\text {EMEP_c }}(6.42 \mathrm{ppb})$, but is for both cases far below the measured value of $23 \mathrm{ppb}$. At
HU02 $\mathrm{NH}_{3} \mathrm{~S}_{\text {EMEP }}$ is $3.01 \mathrm{ppb}$ and $\mathrm{NH}_{3} \mathrm{~S}_{\text {EMEP_c }}$ is $3.20 \mathrm{ppb}$, which agrees better to the measured mean concentration of $3.52 \mathrm{ppb}$. It seems that the spatial variability of measured $\mathrm{NH}_{3}$ is too large to prove that the modelled $\mathrm{NH}_{3}$ improves when including high time resolution.

In December, $S_{E M E P}$ and $S_{E M E P} \_c$, correlate on average better than in June, and the concentrations deviate less strongly, indicating that also in other regions, in winter boundary layer mixing plays a less important role. Clearly including the hourly and daily emission-variability can not explain all model-measurement differences.

Differences in precursor concentrations $\left(\mathrm{NH}_{3}, \mathrm{NO}_{\mathrm{x}}\right)$ lead to differences in the calculated nitrate aerosol, which are smaller in all cases for $\mathrm{S}_{\mathrm{EMEP}}$ in June (up to $30 \%$ ). In December, when model results of $\mathrm{S}_{\text {EMEP }}$ and $\mathrm{S}_{\text {EMEP_c }}$ can be compared to artefact-free $\mathrm{NO}_{3}^{-}$aerosol measurements (ES Table S19, 16 stations, including stations with temporal correlation coefficient smaller than 0.5 ) differences are rather small and do not lead to a clear improvement. For most longer-lived species the impact of daily and weekly emissions factors is smaller than $1-2 \%$. The explanation for this observation is that for species that have a lifetime of more than a day, advective fluxes are dominating and mask the short-term emission variations. 
Table 4. Averaged computed $\left(\mathrm{S}_{\mathrm{EMEP}}\right.$ and $\mathrm{S}_{\mathrm{EMEP} \_\mathrm{c}}$ ) and observed $\mathrm{NO}_{3}^{-}$aerosol concentrations, together with the corresponding temporal correlation coefficient of all the stations, for December 2000.

\begin{tabular}{|c|c|c|c|c|c|}
\hline & \multicolumn{5}{|c|}{ December $\mathrm{NO}_{3}^{-}$aerosol } \\
\hline & $\begin{array}{l}\text { Monthly mean } \\
\text { ppb } S_{\text {EMEP }}\end{array}$ & $\mathrm{r}$ & $\begin{array}{l}\text { Monthly mean } \\
\text { ppb SEMEP_C }\end{array}$ & $\mathrm{r}$ & $\begin{array}{l}\text { EMEP ppb } \\
\text { measurements }\end{array}$ \\
\hline $\begin{array}{l}\text { December aver- } \\
\text { age }\end{array}$ & $1.40 \pm 0.93$ & 0.45 & $1.41 \pm 0.92$ & 0.44 & $0.93 \pm 0.62$ \\
\hline
\end{tabular}

Table 5. Averaged computed ( $\mathrm{S}_{\mathrm{EMEP} \_c}$ and $\mathrm{S}_{\mathrm{EMEP} \_a n n u a l}$ ) and observed $\mathrm{SO}_{4}^{=}$aerosol, $\mathrm{BC}$ and POM concentrations and the corresponding temporal correlation coefficient of all the stations, for June 2000.

\begin{tabular}{llll}
\hline & $\mathrm{SO}_{4}^{=} \mathrm{ppb} \mathrm{S}_{\text {EMEP_c }}$ & $\mathrm{SO}_{4}^{=} \mathrm{ppb} \mathrm{S}_{\text {EMEP_C_annual }}$ & EMEP ppb data \\
\hline Average & $0.64 \pm 0.50$ & $0.72 \pm 0.56$ & $0.60 \pm 0.39$ \\
& $\mathrm{BC} \mu \mathrm{g} / \mathrm{m}^{3} \mathrm{~S}_{\text {EMEP_c }}$ & $\mathrm{BC} \mu \mathrm{g} / \mathrm{m}^{3} \mathrm{~S}_{\text {EMEP_C_annual }}$ & EMEP data June $2003 \mu \mathrm{g} / \mathrm{m}^{3}$ \\
Average & $0.31 \pm 0.20$ & $0.40 \pm 0.26$ & 0.64 \\
& $\mathrm{POM} \mu \mathrm{g} / \mathrm{m}^{3} \mathrm{~S}_{\text {EMEP_c }}$ & $\mathrm{POM} \mu \mathrm{g} / \mathrm{m}^{3} \mathrm{~S}_{\text {EMEP_C_annual }}$ & OC EMEP data June $2003 \mu \mathrm{g} / \mathrm{m}^{3}$ \\
Average & $0.63 \pm 0.47$ & $0.76 \pm 0.54$ & 4.85 \\
\hline
\end{tabular}

\subsubsection{The impact of monthly emission variations}

In this section we show that the seasonal distribution of emissions has a stronger impact on simulated $\mathrm{SO}_{4}^{=}, \mathrm{BC}$ and POM concentrations than the hourly and daily variations. In our discussion we focus on June, similar effects but opposite in sign can be found for December. In ES Table S20 (http://www.atmos-chem-phys.net/6/4287/2006/ acp-6-4287-2006-supplement.pdf) we present the monthly mean concentrations for sulphate aerosol, BC and POM for June 2000. For BC and POM we compare measurement data of June 2003 (no measurement data available for 2000).

In June, the use of annual average emissions ( $\left.\mathrm{S}_{\mathrm{EMEP} \_c \_a n n u a l}\right)$ leads in general to higher emissions of e.g. $\mathrm{SO}_{2}$ and $\mathrm{NO}_{\mathrm{x}}$, since the intensity of residential and commercial heating, is less during summer than in winter. As a consequence, aerosol and aerosol precursor concentrations are generally higher in simulation $\mathrm{S}_{\mathrm{EMEP} \_c \_a n n u a l}$. For instance, at Jarczew (PL02) the monthly mean $\mathrm{SO}_{2}$ concentration increases from $1.57 \mathrm{ppb}\left(\mathrm{S}_{\mathrm{EMEP} \_\mathrm{c}}\right)$ to $2.26 \mathrm{ppb}$ (SEMEP_c_annual); compared to a measured monthly mean of $1.57 \mathrm{ppb}$. For $\mathrm{NH}_{3}$ again large differences up to $30 \%$ at the stations between $\mathrm{S}_{\mathrm{EMEP} \_c}$ and $\mathrm{S}_{\mathrm{EMEP} \_c \text { _annual }}$ are found. $\mathrm{NH}_{3}$ concentrations computed by $\mathrm{S}_{\text {EMEP_c }}$ are higher, which demonstrates the application of higher emission factors for $\mathrm{NH}_{3}$ emissions during the summer months (agricultural activities are higher during summer months than in winter); but again it is difficult to discern better model performance on the basis of a few stations.

Differences in $\mathrm{NO}_{\mathrm{x}}$ concentrations between $\mathrm{S}_{\text {EMEP_c }}$ and $\mathrm{S}_{\text {EMEP_c_annual }}$ are small (up to $8 \%$ higher by $\mathrm{S}_{\text {EMEP_c_annual }}$ ). For the majority of the stations the $\mathrm{NO}_{\mathrm{x}}$ concentrations by

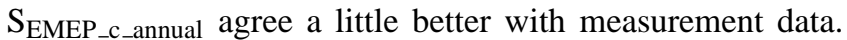
However, on average, the modelled $\mathrm{NO}_{\mathrm{x}}$ concentrations of $\mathrm{S}_{\text {EMEP_c }}$ and $\mathrm{S}_{\text {EMEP_c_annual }}$ are the same $(5.71 \mathrm{ppb})$ and in reasonable agreement with the measured values $(4.48 \mathrm{ppb}$; $27 \%$ higher).

The larger $\mathrm{SO}_{2}$ emissions also increase the calculated $\mathrm{SO}_{4}^{=}$ concentrations comparing $\mathrm{S}_{\mathrm{EMEP} \_c \_a n n u a l}$ with $\mathrm{S}_{\mathrm{EMEP} \_c}$. For sulphate aerosol we have a substantial amount of measurements available allowing for robust evaluation of the improvement resulting from using seasonally resolved emissions. Like in Sect. 4.1, in our analysis we excluded 30 stations for which the temporal correlation coefficient of model results with measurement data is less than 0.5. In June, in all 41 cases $\mathrm{SO}_{4}^{=}$by $\mathrm{S}_{\text {EMEP_c }}$ is lower than by $\mathrm{S}_{\text {EMEP_c_annual }}$, and agree better with measurement data. The mean concentrations averaged for all stations (Table 5) are $0.64 \pm 0.50$ for $S_{E M E P \_c}, 0.72 \pm 0.56(\mathrm{ppb})$ for $\mathrm{S}_{\mathrm{EMEP} \_c \_a n n u a l}$ and for the measurements $0.60 \pm 0.39$ (ppb).

Monthly mean BC concentrations (Table 5) by

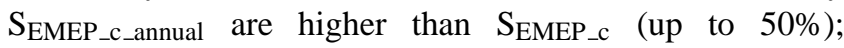
however on average both simulations seem to substantially underestimate $\mathrm{BC}$ in June. Note again that we have compared to data obtained in June 2003, since no observations are available for 2000. We find differences up to $40 \%$ in POM monthly mean concentrations between the $\mathrm{S}_{\text {EMEP_c }}$

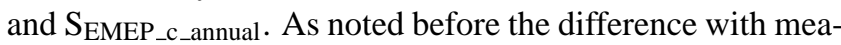
sured OC is very large, associated with the neglect of SOA formation. We used a constant factor of 1.4 in the conversion from POM to OC. While this factor is fairly uncertain, the value for this factor was chosen for consistency with the assumptions made in the AEROCOM database. 
Table 6. Averaged computed ( $\mathrm{S}_{\text {EMEP_c }}$ and $\mathrm{S}_{\text {EMEP_annual }}$ ) and observed AOD values of all the stations, together with the corresponding temporal correlation coefficient for June 2000.

\begin{tabular}{|c|c|c|c|c|c|}
\hline & $\begin{array}{l}\text { Monthly mean + sdev AOD } \\
\text { SEMEP_C }\end{array}$ & r. & $\begin{array}{l}\text { Monthly mean + sdev AOD } \\
\text { SEMEP_C_annual }\end{array}$ & r. & $\begin{array}{l}\text { Monthly mean + sdev AOD } \\
\text { AERONET }\end{array}$ \\
\hline Average & $0.15 \pm 0.15$ & 0.22 & $0.16 \pm 0.16$ & 0.23 & $0.19 \pm 0.11$ \\
\hline
\end{tabular}

What is the impact of the emission variability on calculated AOD?

The substantial differences found between the monthly concentrations of $\mathrm{S}_{\mathrm{EMEP} \_c}$ and $\mathrm{S}_{\mathrm{EMEP} \_ \text {_annual }}$ translate in relatively small $(<10 \%)$ differences in AOD calculations, consistent with the deviation of the main contributing inorganic sulphate concentrations. Comparison of $S_{E M E P} \_c$ and SEMEP_c_annual modelled AOD with the AERONET stations (Table 6) shows that on average AOD for S SEEP_c_annual $(0.16)$ is getting slightly better agreement with AERONET (0.19) than S SEEP_c $(0.15)$. AOD values for the stations can be found in ES, Table 21.

\section{Discussion}

We showed that despite the over-all annual and European scale agreement, large differences in the geographical distributions of EMEP and AEROCOM emission inventories were found. In addition we showed the strong influence of the recommended vertical distribution of the emissions on the distribution of aerosol precursor gases. The differences were translated in relatively large divergences of $\mathrm{NO}_{\mathrm{x}}$ and $\mathrm{SO}_{2}$ concentrations where especially the AEROCOM recommended emissions tend to overestimate measured $\mathrm{NO}_{\mathrm{x}}$ (from EDGAR3.2 database), $\mathrm{SO}_{2}$ and to a lesser extend $\mathrm{SO}_{4}^{=}$concentrations for June 2000 when compared with EMEP measurement data.

Some studies (e.g. Pont and Fontan, 2001; Pryor and Steyn, 1995; Jenkin et al., 2002) have previously evaluated the impact of temporal distribution of emissions on $\mathrm{O}_{3}$ concentrations. These studies demonstrated that the temporal variation of precursor emissions $\mathrm{NO}_{\mathrm{x}}$ and $\mathrm{VOC}$ are resulting in a day-of-week dependence of $\mathrm{O}_{3}$ concentrations. Schaap et al. (2003) showed the role of seasonal variation of $\mathrm{NH}_{3}$ emissions on the $\mathrm{NH}_{3}$ and $\mathrm{NO}_{3}$ aerosol calculations. Our study confirmed latter study that the daily and weekly distribution of emissions is important for $\mathrm{NH}_{3}, \mathrm{NO}_{\mathrm{x}}$ and $\mathrm{NO}_{3}$ calculations. In addition we demonstrated that the additional information from daily and weekly time resolution is not very important for $\mathrm{SO}_{2}$, and $\mathrm{SO}_{4}^{=}, \mathrm{BC}$ and $\mathrm{POM}$ calculations; however monthly variations of the emissions can strongly impact the calculated concentrations. Therefore, a major improvement of the current global inventories of aerosol and aerosol precursor would be a systematic evaluation of the seasonal cycle of anthropogenic emissions. The strong influence of the emission height on our calculations was somewhat surprising. Processing of emission in models seems to be more important than emissions themselves, indicating that each model has "a mind of its own", and therefore largely independent of emissions input. Similar results were obtained when harmonizing aerosol emissions in AeroCom Exp. B, Textor et al. (2006). Little information is available on emission heights of anthropogenic emissions. The recommended emissions height used for AEROCOM inventory was based on expert judgement and not on data; whereas the EMEP height recommendation is based on only very few bottom-up studies on emission heights; and the recommendations may be strongly biased. Surprisingly within Europe there is no compilation available about the stack-heights of large point source; nor about the plume rise associated with them. Effective plume rise of other sources are not known.

We showed that a further uncertainty is introduced by the desegregation of PM2.5 emissions in the EMEP inventory into aerosol components; where especially BC concentrations are for both the months underestimated compared to the measurement data. A bottom-up approach retaining as much as possible information on aerosol size and composition would be desirable for future European inventories. We further showed the sensitivity of model results to the assumed seasonal distribution of $\mathrm{NH}_{3}$ emissions; for which relatively little is available.

The AEROCOM inventory also contained pseudoemissions for secondary organic aerosol. Indeed it was shown that the secondary organic aerosol may several times exceed the primary organic aerosols. At present, some global and regional models include parameterisations of organic aerosol formation. However, as discussed by Kanakidou et al. (2005) uncertainties in the SOA formation are at least a factor of two, which results in difficult to quantify uncertainties in the European aerosol budget.

Despite substantial differences in calculated aerosol concentrations at the Earth's surface the associated AOD was less different. In both simulations the highest AOD was related to regions with high relative humidity, in the vicinity of clouds. In these areas of high $R H(>90 \%)$, large quantities of water on inorganic aerosol are calculated $(>50 \mu \mathrm{g} / \mathrm{m} 3)$. MODIS does not report successful AOD retrieval for these areas. Whether or not this aerosol should be classified as cloud or rather as aerosol with a large water fraction is an 

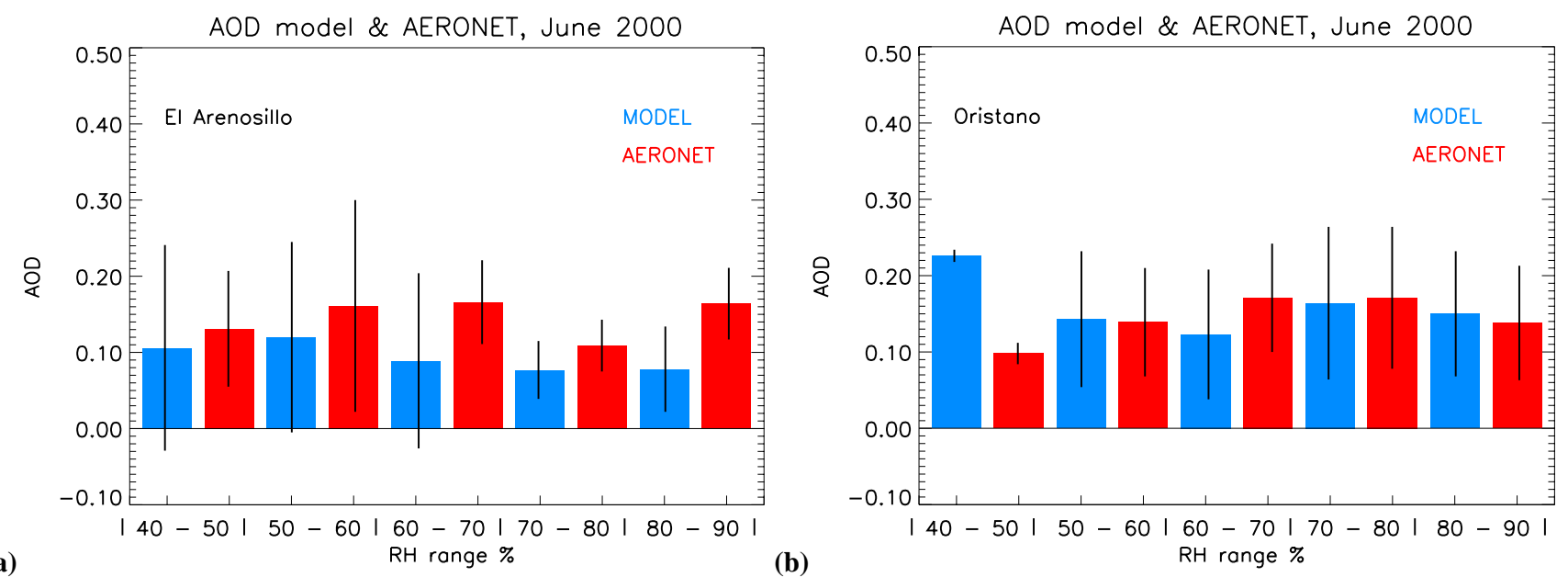

(a)

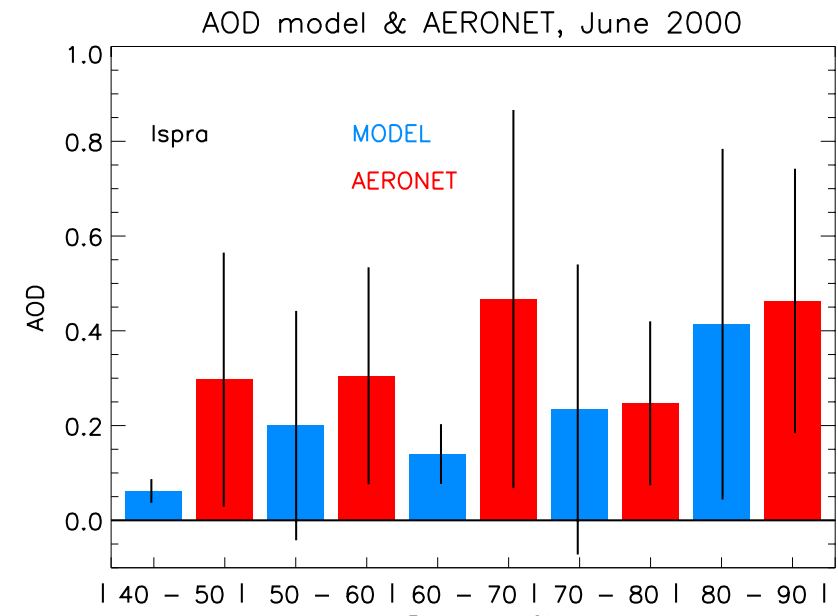

(c)

$\mathrm{RH}$ range \% (b)

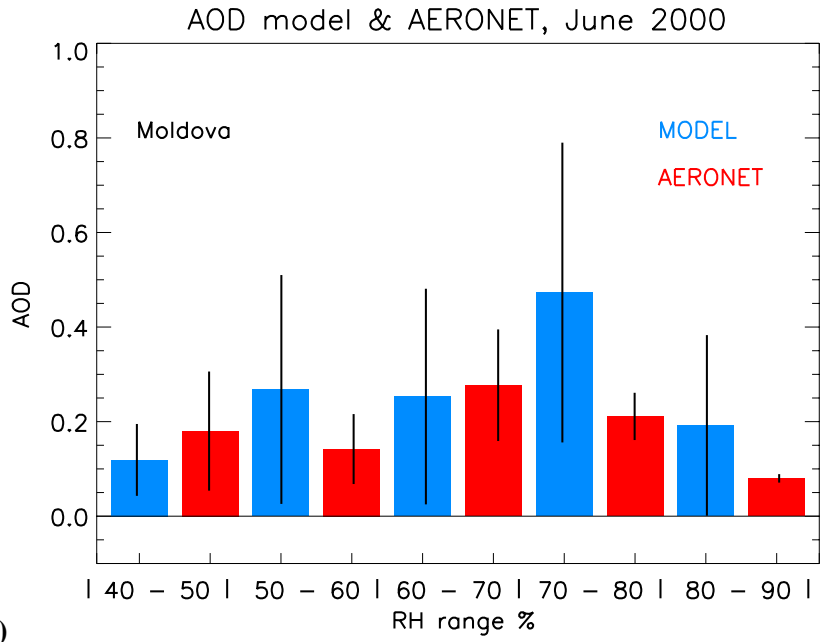

(d)

AOD model \& AERONET, June 2000

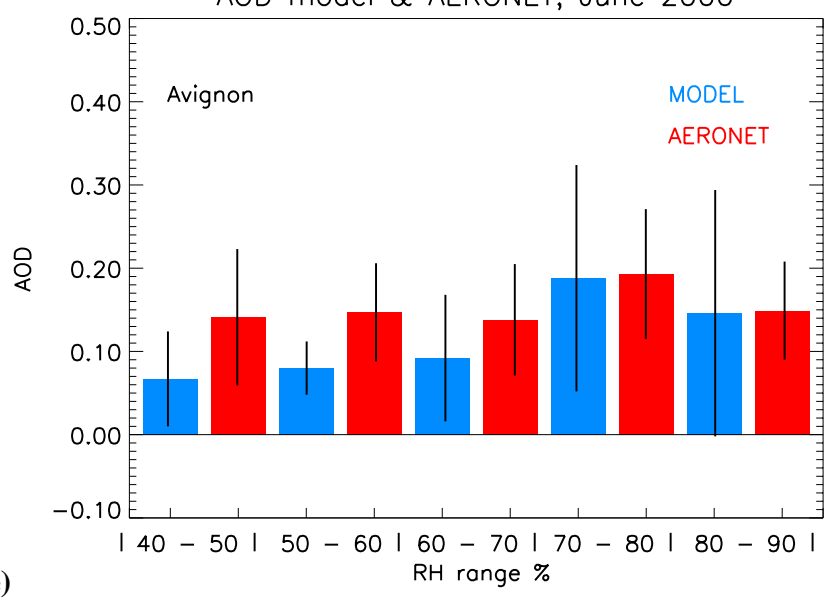

Fig. 7. AOD calculated by the model (blue) and observed by AERONET (red) at different relative humidity ranges (40-50\%, 50-60\%, 60-70\%, 70-80\%, 80-90\%), for El Arenosillo (a), IMC Oristano (b), Ispra (c), Moldova (d) and Avignon (e) for June 2000. The black line presents the standard deviation. 
open question. However, we do think that these aerosols are frequently present and are often not "seen" by satellite retrievals.

From the model point of view the aerosol equilibrium model used in our study (EQSAMv_03d), or any other equilibrium model, is not tested for high relative humidity, rendering the calculations of aerosol water rather uncertain.

Whether the AOD calculation by the model strongly depends on the $R H$ (influence of $R H$ on aerosol water) or does the model underestimate/overestimate aerosol concentrations, we present in Fig. 7 the $R H$ dependency of AOD calculation.

At low $R H$ ranges (i.e. $40-50 \%, 50-60 \%, 60-70 \%$ ) we see that the model calculated AOD is too low when compared to AERONET. This indicates that the concentrations of (inorganic) aerosols is too low for this areas. The larger standard deviations for El Arenosillo at low $R H$ is due to the presence of aerosol dust, leading to higher AOD peak values. The high AOD model value for Oristano at $R H 40-50 \%$ is based on a few hours only and therefore not statistically robust.

At higher $R H$ ranges (70-80\%, 80-90\%) larger standard deviations are found when compared to AERONET, indicating the non-linear effect of $R H$ on aerosol water calculations, which contribute to the overestimation of the AOD values.

We evaluated the effects of assuming the "water-soluble aerosol accumulation/aitken mode" according to the Whitby distribution with 2 other distributions as presented in Table 4.2 in the d'Almeida climatology $(\mathrm{r}=0.0285 \mu \mathrm{m}$ and sigma $=2.239$ ) and Putaud et al. (2003) who present a host of log-normal fits to observed size distributions at various locations in Europe. E.g. at the rural location Ispra Mode 2 parameters $\mathrm{r}=0.024 \mu \mathrm{m}$ and sigma $=1.91$. Using these parameters we calculate that the extinction coefficient would differ from the assumed Whitby distribution by 3\% (higher) and $15 \%$ (lower), respectively.

\section{Conclusions}

Based on the analysis presented above it appears that the AEROCOM inventory overestimates the emissions of aerosol precursor gases $\mathrm{SO}_{2}$ and $\mathrm{NO}_{\mathrm{x}}$ and $\mathrm{NH}_{3}$ emissions, especially in June. This overestimate is the combined effect of a lack in seasonal variation in the AEROCOM inventory and the different vertical distribution of emissions $\left(\mathrm{SO}_{2}\right.$ and $\left.\mathrm{NO}_{\mathrm{x}}\right)$. For $\mathrm{NH}_{3}$ is seems that the inclusion of recent abatement measures in the EMEP inventory (see Sect. 2.3.3) indeed leads to a better agreement with measured concentrations.

The height distribution of the emissions is obviously a less important factor for AOD values than for surface concentrations.

We evaluated the impact of the EMEP and AEROCOM emission inventories on aerosol concentrations and aerosol optical depth (AOD) in Europe for June and December 2000. There are substantial differences between annual emissions included in the two inventories, e.g. mineral dust emissions are $40 \%$ lower and $\mathrm{NH}_{3}$ emissions are $18 \%$ higher comparing AEROCOM and EMEP emissions. The differences between AEROCOM and EMEP emissions are in general augmented in June (factors of 1.00-2.48) compared to December (factors $0.71-1.21)$.

Especially for $\mathrm{SO}_{2}$ and $\mathrm{NO}_{\mathrm{x}}$ differences occur also in the vertical distribution profile of the emissions. Despite these differences, for most aerosol species and aerosol precursor gases TM5 simulates the spatial and temporal distribution over Europe relatively well. Spatial correlations, based on monthly mean concentrations are often quite high and many EMEP measurement stations show high temporal correlation with $\mathrm{S}_{\mathrm{EMEP}}$ and $\mathrm{S}_{\mathrm{AERO}}$.

However, a better agreement of surface concentrations of aerosol precursors $\mathrm{SO}_{2}, \mathrm{NO}_{\mathrm{x}}$ and aerosol $\mathrm{NH}_{4}^{+}$are calculated with the EMEP emissions inventory for June, while $\mathrm{SO}_{4}^{=}$for both simulations compares well to observations. Similar discrepancies are found in December, with the difference that $\mathrm{SO}_{4}^{=}$is underestimated by a factor of two using both inventories. At the only station available in 2000 for comparison (Ispra), black carbon concentrations calculated with both inventories agree within $\pm 40 \%$ with the measured concentrations in June and December, respectively; a comparison with measurements from other years/locations indicated in general a large underestimate of computed BC.

The large differences in surface concentrations between the simulations are not equally reflected in corresponding differences in computed column aerosol and AOD. In June, model AOD computations using the AEROCOM and EMEP emission inventories reveal good agreement with surface based AERONET sun photometer observations and AOD retrieved from MODIS. Spatial patterns over Europe of AOD differ due to the varying contributions of mineral dust and inorganic aerosol, as observed by satellite and confirmed by model simulations. An evaluation of the impact on aerosol of the temporal distribution (daily, weekly and seasonal) of emissions reveals that the concentrations of most aerosol components are not strongly influenced by introduction of a high temporal resolution of emissions. The exception is aerosol nitrate and its precursor gases $\mathrm{NO}_{\mathrm{x}}$, and $\mathrm{NH}_{3}$.

However, seasonal temporal variation of the emissions do play an important role for all gas and aerosol calculations, and need to be included to accurately calculate aerosol concentrations and its influence on climate.

Global scale emission inventories such as used for AEROCOM may provide a reasonable first estimate for computation of aerosol precursor and aerosol concentrations. However, global inventories will strongly benefit from information from regional scale inventories, such as EMEP, especially with regard to knowledge on seasonality of emissions, and spatial and vertical distribution of these emissions. The challenge for future global inventories will be to include this regional knowledge, while maintaining the global consistency and transparency. 
Acknowledgements. We acknowledge S. Metzger who provided the EQSAM_v03d aerosol module and O. Boucher for providing his Mie code.

Monthly and daily emission distributions have been prepared by the Institute of Energy Economics and the Rational Use of Energy, University of Stuttgart (D). The hourly variations are provided by TNO Environment, Energy and Process Innovation (NL).

We would like to thank EMEP for compiling the emission inventory, as used in the EURODELTA exercise (http://aqm.jrc.it/eurodelta). The AERONET principal investigators are acknowledged for their continuous effort in collecting AOD data. We thank Goddard Distributed Active Archive Center (DAAC) for providing MODIS data.

Edited by: M. G. Lawrence

\section{References}

Bergamaschi, P., Krol, M., Dentener, F., Vermeulen, A., Meinhardt, F., Graul, R., Ramonet, M., Peters, W., and Dlugokencky, E. J.: Inverse modelling of national and European $\mathrm{CH}_{4}$ emissions using the atmospheric zoom model TM5, Atmos. Chem. Phys., 5, 2431-2460, 2005,

http://www.atmos-chem-phys.net/5/2431/2005/.

Bond, T. C., Streets, D. G., Yarber, K. F., Nelson, S. M., Woo, J.H., and Klimont, Z.: A technology-based global inventory of black and organic carbon emissions from combustion, J. Geophys. Res., 109, D14203, doi:10.1029/2003JD003697, 2004.

Bouwman, A. F., Lee, D. S., Asman, W. A. H., Dentener, F. J., Van Der Hoek, K. W., and Olivier, J. G. J.: A global high-resolution emission inventory for ammonia, Global Biogeochem. Cycles, 11(4), 561-588, 1997.

Bouwman, A. F., Boumans, L. J. M., and Batjes, N. H.: Estimation of global NH3 volatilization loss from synthetic fertilizers and animal manure applied to arable lands and grasslands, Global Biogeochem. Cycles, 16(2), 1024, doi:10.1029/2000GB001389, 2002.

Charlson, R. J., Langner, J., Rodhe, H., Leovy, C. B., and Warren, S. G.: Perturbation of northern hemisphere radiative balance by backscattering from anthropogenic sulphate aerosols, Tellus, Ser. B. 43, 152-163, 1991.

Chin, M., Chu, A., Levy, R., Remer, L., Kaufman, Y., Holben., B., Eck, T., Ginoux, P., and Gao, Q.: Aerosol distribution in the Northern Hemisphere during ACE-Asia: Results from global model, satellite observations, and Sun photometer measurements, J. Geophys. Res., 109, D23S90, doi:10.1029/2004JD004829, 2004.

Cofala, J., Amann, M., and Mechler, R.: Scenarios of world anthropogenic emissions of air pollutants and methane up to 2030, Tech. rep., International Institute for Applied Systems Analysis (IIASA), Laxenburg, Austria, available from: http://www.iiasa. ac.at/rains/global_emiss/global_emiss.html, 2005.

d'Almedia, G. A.: A model for Saharan dust transport, J. Climatol. Appl. Meteorol., 25, 903-916, 1986.

Dentener, F. J. and Crutzen, P. J.: Reaction of N2O5 on tropospheric aerosols: Impact on the global distributions of $\mathrm{NOx}, \mathrm{O} 3$, and $\mathrm{OH}$, J. Geophys. Res. 98, 7149-7163, 1993.

Dentener, F. J. and Crutzen, P. J.: A three-dimensional model of the global ammonia cycle, J. Atmos. Chem., 19, 331-369, 1994.
Dentener, F., Weele, M. V., Krol, M. C., Houweling, S., and Velthoven, P. V.: Trends and inter-annual variability of methane emissions derived from 1979-1993 global CTM simulations, Atmos. Chem. Phys., 3, 73-88, 2003,

http://www.atmos-chem-phys.net/3/73/2003/.

Dentener, F., Kinne, S., Bond, T., Boucher, O., Cofala, J., Generoso, S., Ginoux, P., Gong, S., Hoelzemann, J. J., Ito, A., Marelli, L., Penner, J., Putaud, J.-P., Textor, C., Schulz, M., Van der Werf, G. R., and Wilson, J.: Emissions of primary aerosol and precursor gases in the years 2000 and 1750 prescribed data-sets for AeroCom, Atmos. Chem. Phys. Discuss., 6, 2703-2763, 2006, http://www.atmos-chem-phys-discuss.net/6/2703/2006/.

Downing, H. D. and Williams, D.: Optical constants of water in the infrared, J. Geophys. Res., 80, 1656-1661, 1975.

Eck, T. F., Holben, B. N., Reid, J. S., Dubovik, O., Smirnov, A., O'Neill, N. T., Slutsker, I., and Kinne, S.: Wavelength dependence of the optical depth of biomass burning, urban and desert dust aerosols, J. Geophys. Res., 104, 31 333-31 350, 1999.

EMEP: Transboundary acidification, eutrophication and ground level ozone in Europe, Status report 1/2004, Norwegian Meteorological Institute, ISSN 0806-4520, August 2004.

Ganzeveld, L., Lelieveld, J., and Roelofs, G.-J.: A dry deposition parameterization for sulfur oxides in a chemistry and general circulation model, J. Geophys. Res., 103, 5679-5694, 1998.

Gerber, H. E.: Relative-humidity parameterization of the Navy aerosol model (NAM), NRL Rep. 8956, Natl. Res. Lab., Washington, D.C., 1985.

Gery, M. W., Whitten, G. Z., and Killus, J. P.: Development and testing of the CBM-IV for urban and regional modelling, EPA600/3-88-012. U.S. EPA, Research Triangle Park, 1989.

Gery, M. W., Whitten, G. Z., Killus, J. P., and Dodge, M. C.: A photochemical kinetics mechanism for urban and regional scale computer modelling, J. Geophys. Res., 94D, 12 925-12956, 1989.

Ginoux, P., Prospero, J. M., Torres, O., and Chin, M.: Longterm simulation of global dust distribution with the GOCART model: Correlation with North Atlantic Oscillation., Env. Mod. and Soft., 19(2), 113-128, 2004.

Gong, S. L., Barrie, L. A., and Lazare, M.: Canadian Aerosol Module (CAM): A size-segregated simulation of atmospheric aerosol processes for climate and air quality models 2. Global sea-salt aerosol and its budgets, J. Geophys. Res., 107(D24), 4779, doi:10.1029/2001JD002004, 2002.

Gong, S. L. and Barrie, L. A.: Simulating the impact of sea salt on global nss sulphate aerosols, J. Geophys. Res., 108(D16), 4516, doi:10.1029/2002JD003181, 2003.

Gong, S. L.: A parameterization of sea-salt aerosol source function for sub- and super-micron particles, Global Biogeochem. Cycles, 17(4), 1097, doi:10.1029/2003GB002079, 2003.

Guelle, W., Balkanski, Y. J., Schultz, M., Dulac, F., and Monfray, P.: Wet deposition in a global size-dependent aerosol transport model, 1. Comparison with 1 year $210 \mathrm{~Pb}$ simulation with ground measurements, J. Geophys. Res., 103, 11 429-11445, 1998.

Halmer, M. M., Schmincke, H. U., and Graf, H. F.: The annual volcanic gas input into the atmosphere, in particular into the stratosphere: a global data set for the past 100 years, J. Volc. Geo. Res. 115, 511-528, 2002.

Hertel, O., Berkowicz, R., and Christensen, J.: Test of two numerical schemes for use in atmospheric transport-chemistry models, 
Atmos. Environ., 27A, 16, 2591-2611, 1993.

Hess, M., Koepke, P., and Schult, I.: Optical properties of aerosols and clouds: The software package OPAC, Bull. Am. Meteorol. Soc., 79, 831-844, 1998.

Holben, B., Eck, T., Slutsker, I., Tanré, D., Buis, J., Vermote, E., Reagan, J., Kaufman, Y., Nakajima, T., Lavenau, F., Jankowiak, I., and Smirnov, A.: AERONET, a federated instrument network and data-archive for aerosol characterization, Rem. Sens. Environ., 66, 1-66, 1998.

Houweling, S., Dentener, F., and Lelieveld, J.: The impact of nonmethane hydrocarbon compounds on tropospheric photochemistry, J. Geophys. Res., 103, 10 637-10 696, 1998.

Jacobson, M. Z.: Strong radiative heating due to the mixing state of black carbon in atmospheric aerosols, Nature, 409(6821), 695697, 2001.

Jenkin, M. E., Davies, T. J., and Stedman, J. R.: The origin and day-of-week dependence of photochemical ozone episodes in the UK, Atmos. Environ., 36, 999-1012, 2002.

Jeuken, A.: Evaluation of chemistry and climate models using measurements and data assimilation, $\mathrm{PhD}$ thesis, Eindhoven University of Technology, 2000.

Jeuken, A., Veefkind, P., Dentener, F., Metzger, S., and RoblesGonzalez, C.: Simulation of the aerosol optical depth over Europe for August 1997 and a comparison with observations, J. Geophys. Res., 106, 28 295-28 311, 2001.

Kanakidou, M., Seinfeld, J. H., Pandis, S. N., Barnes, I., Dentener, F. J., Facchini, M. C., Van Dingenen, R., Ervens, B., Nenes, A., Nielsen, C. J., Swietlicki, E., Putaud, J. P., Balkanski, Y., Fuzzi, S., Horth, J., Moortgat, G. K., Winterhalter, R., Myhre, C. E. L., Tsigaridis, K., Vignati, E., Stephanou, E. G., and Wilson, J.: Organic aerosol and global climate modelling: a review, Atmos. Chem. Phys., 5, 1053-1123, 2005,

http://www.atmos-chem-phys.net/5/1053/2005/.

Kasibhatla, P., Chameides, W. L., and John, J. S.: A threedimensional global model investigation of seasonal variations in the atmospheric burden of anthropogenic sulphate aerosols, J. Geophys. Res., 102, 3737-3759, 1997.

Kaufman, Y. J., Tanré, D., Remer, L. A., Vermote, E. F., Chu, A., and Holben, B. N.: Operational remote sensing of tropospheric aerosols over land form EOS-Moderate Resolution Imaging Spectroradiometer, J. Geophys. Res., 102, 17 051-17065, 1997.

Kettle, A. and Andreae, M.: Flux of dimethylsulfide from the oceans: A comparison of updated data sets and flux models. J. Geophys. Res., 105, 26 793-26 808, 2000.

Kiehl, J. T. and Briegleb, P. B.: The relative roles of sulphate aerosols and greenhouse gases in climate forcing, Science, 260, 311-314, 1993.

Kinne, S., Schulz, M., Textor, C., Guibert, S., Bauer, S., Berntsen, T., Berglen, T., Boucher, O.,Chin, M., Dentener, F., Diehl, T., Feichter, H., Fillmore, D., Ghan, S., Ginoux, P., Gong, S., Grini, A., Hendricks, J., Horowitz, L., Isaksen, I., Iversen, T., Koch, D., Krol, M., Lauer, A., Lamarque, J. F., Liu, X., Montanaro, V., Myhre, G., Penner, J., Pitari, G., Reddy, S., Seland, O., Stier, P., Takemura, T., and Tie, X.: An AeroCom initial assessment - optical properties in aerosol component modules of global models, Atmos. Chem. Phys., 6, 1815-1834, 2006, http://www.atmos-chem-phys.net/6/1815/2006/.

Krol, M., Houweling, S., Bregman, B., Van den Broek, M., Segers,
A., Van Velthoven, P., Peters, W., Dentener, F., and Bergamaschi, P.: The two-way nested global chemistry-transport zoom model TM5: algorithm and applications, Atmos. Chem. Phys., 5, 417 432, 2005,

http://www.atmos-chem-phys.net/5/417/2005/.

Lowenthal, D. H., Watson, J. G., and Saxena, P.: Contributions to light extinction during project MOHAVE, Atmos. Environ., 34, 2351-2359, 2000.

Metzger, S.: Gas/Aerosol partitioning: A simplified Method for Global Modelling, Ph.D. Thesis, University of Utrecht, http://www.library.uu.nl/vakgebieden/natuurensterrenk/ 11067main.html, 2000.

Metzger, S., Dentener, F., Pandis, S., and Lelieveld, J.: Gas/aerosol partitioning: 1. A computationally efficient model, J. Geophys. Res., 107, D16, doi:1-.1029/2001JD001102, 2002.

Metzger, S., Dentener, F., Krol, M., Jeuken, A., and Lelieveld, J.: Gas/Aerosol partitioning 2. Global modeling results, J. Geophys. Res., 107(D16), 4313, doi:10.1029/2001JD001103, 2002.

Nightingale, P. D., Malin, G., Law, C. S., Watson, A. J., Liss, P. S., Liddicoat, M. I., Boutin, J., and Upstill-Goddard, R. C.: In situ evaluation of air-sea gas exchange parameterizations using novel conservative and volatile tracers, Global Biogeochem. Cycles, 14(1), 373-387, 2000.

Pandis, S. N. and Seinfeld, J. H.: Sensitivity analysis of a chemical mechanism for aqueous-phase atmospheric chemistry, J. Geophys. Res., 94, 1105-1126, 1989.

Peters, W., Krol, M. C., Dentener, F., Thompson, A. M., and Lelieveld, J.: Chemistry-transport modeling of the satellite observed distribution of tropical tropospheric ozone, Atmos. Chem. Phys., 2, 103-120, 2002, http://www.atmos-chem-phys.net/2/103/2002/.

Peters, W., Krol, M. C., Bruhwiler, L., Dlugokencky, E. J., Dutton, G., Miller, J. B., Bergamaschi, P., Dentener, F. J., Van Velthoven, P., and Tans, P. P.: Towards regional scale inversion using a two-way nested global model: Characterization of transport using SF6, J. Geophys. Res., 109, D19314, doi:10.1029/2004JD005020, 2004.

Pham, M., Müller, J.-F, Brasseur, G. P., Granier, C., and Megie, G.: A three-dimensional study of the tropospheric sulfur cycle, J. Geophys. Res., 100(D12), 26 061-26 092, 95JD02095, 1995.

Pont, V. and Fontan, J.: Comparison between weekend and weekday ozone concentration in large cities in France, Atmos. Environ., 35, 1527-1535, 2001.

Pryor, S. C. and Steyn, D. G.: Hebdomadal and diurnal cycles in ozone time series from the Lower Fraser Valley, B.C., Atmos. Environ., 29(2), 1007-1019, 1995.

Putaud, J. P., Van Dingenen, R., Baltensperger, U., et al.: A European aerosol phenomenology, Joint Research Centre, Institute for Environment and Sustainability, European Commission, 2003.

Remer, L. A., Kaufman, Y. J., Tanré, D., Mattoo, S., Chu, D. A., Martins, J. V., Li, R.-R., Ichou, C., Levy, R. C., Kleidman, R. G., Eck, T. F., Vermote, E., and Holben, B. N.: The MODIS Aerosol Algorithm, Products, and Validation, J. Atmos, Sci., Special Section, 62, 947-973, 2005.

Riemer, N., Vogel, H., Schell, B., Ackermann, I., Kessler, C., and Hass, H.: Impact of the heterogeneous hydrolysis of N2O5 on chemistry and nitrate aerosol formation in the lower troposphere under photosmog conditions, J. Geophys. Res., 108(D4), 4144, doi:10.1029/2002JD002436, 2003. 
Russel, G. and Lerner J.: A new finite-differencing scheme for the tracer transport equation, J. Appl. Meteorol., 20, 1483-1498, 1981.

Schaap, M.: On the importance of aerosol nitrate in Europe, Data analysis and modelling, Ph.D. thesis University of Utrecht, http://www.library.uu.nl/digiarchief/dip/diss/ 2003-1209-110044/inhoud.htm, 2003.

Schaap, M., Van Loon, M., Ten Brink, H. M., Dentener, F., and Builtjes, P. J. H.: The nitrate aerosol field over Europe: simulations with an atmospheric chemistry-transport model of intermediate complexity, Atmos. Chem. Phys., 3, 5919-5976, 2003, http://www.atmos-chem-phys.net/3/5919/2003/.

Schaap, M., Denier van der Gon, H. A. C., Visschedijk, A. J. H., Van Loon, M., ten Brink, H. M., Dentener, F. J., Putaud, J.-P., Guillaume, B., Liousse, C., and Builtjes, P. J. H.: Anthropogenic black carbon and fine aerosol distribution over Europe, J. Geophys. Res., 109, D18201, doi:10.1029/2003JD004330, 2004.

Schnaiter, M., Horvath, H., Mohler, O., Naumann, K. H., Saathoff, H., and Schock, O. W.: UV-VIS-NIR spectral optical properties of soot and soot-containing aerosols, J. Aerosol. Sci., 34(10), 1421-1444, 2003.

Shettle, E. P. and Fenn, R. W.: Models for the Aerosols for the Lower Atmosphere and the Effects of Humidity Variations on Their Optical Properties, AFGL-TR-79-0214, Environ. Res. Papers, No. 676, 1979.

Sokolik, I. N. and Toon, O. B.: Incorporation of mineral composition into models of the radiative properties of mineral aerosol from UV to IR wavelengths, J. Geophys. Res., 104, 9423-9444, 1999.
Tanré, D., Kaufman, Y. J., Herman, M., and Mattoo, S.: Remote sensing of aerosol over oceans from EOS-MODIS, J. Geophys. Res., 102, 16971-16988, 1997.

Textor, C., Schulz, M., Guibert, S., Kinne, S., Bauer, S., Balkanski, Y., Berntsen, T., Berglen, T., Boucher, O., Chin, M., Dentener, F., Diehl, T., Feichter, H., Fillmore, D., Ghan, S., Ginoux, P., Gong, S., Grini, A., Hendricks, J., Horrowitz, L., Isaksen, I., Iversen, T., Kirkevag, A., Koch, D., Kristjansson, J. E., Krol, M., Lauer, A., Lamarque, J. F., Liu, X., Montanaro, V., Myhre, G., Penner, J., Pitari, G., Reddy, S., Seland, O., Stier, P., Takemura, T., and Tie, X.: Analysis and quantification of the diversities of aerosol life cycles within AeroCom, Atmos. Chem. Phys., 6, 1777-1813, 2006 , http://www.atmos-chem-phys.net/6/1777/2006/.

Tiedtke, M.: A comprehensive mass flux scheme for cumulus parameterisation in large scale models, Mon. Wea. Rev., 177, 1779-1800, 1989.

Van der Werf, G. R., Randerson, J. T., Collatz, G. J., and Giglio, L.: Carbon emissions from fires in tropical and subtropical ecosystems, Global Change Biology, 9(4), 547-562, 2003.

Vignati, E., Krol, M., and Dentener, F.: Global and regional aerosol modelling: a picture over Europe, in: Advances in Air Pollution Modeling for Environmental Security, edited by: Farago, I., Georgiev, K., and Havasi, A., 373-381, 2005. 